R. GLENN HUBBARD

Northwestern University

KENNETH L. JUDD

Northwestern University

\title{
Liquidity Constraints, Fiscal Policy, and Consumption
}

TAX POLICY AND TAX REFORM are important items on the current policy agenda. In evaluating alternative tax policies, decisionmakers must consider both their normative and positive impact; in particular, they must examine the effects of competing policies on the overall well-being of the taxpayers and on various indexes of economic activity, in both the short run and long run.

Basic to understanding the impact of tax policy is analysis of the relationship between taxation and taxpayers' decisions about consumption, saving, and work effort. Such analysis is especially sensitive to assumptions made regarding individuals' abilities to use capital markets to transfer income across time. By the same token, we think that policy simulation models that ignore "liquidity constraints" result in flawed tax policy analysis. In this paper we analyze the impact of liquidity constraints on consumption functions and use the resulting view of aggregate demand to address two categories of tax and fiscal policy issues.

The first issue is developing a tax system that least reduces taxpayer well-being for the amount of lifetime revenue extracted. Recent applications of theoretically based models of individual behavior have facili-

We are grateful to John Simpson and Nicolas Williams for excellent research assistance and to Mervyn King, Laurence Kotlikoff, and members of the Brookings Panel and the Faculty Research Seminar at the John F. Kennedy School of Government for helpful comments. Financial support from Northwestern University is acknowledged. 
tated comparisons of the effects of alternative policies. Indeed, much of the present debate over the relative reliance on various tax bases and the optimal degree of progressivity of the income tax has been reflected in studies using policy-simulation models. ${ }^{1}$

These models generally assume that individuals or households maximize well-being over their lifetime, subject only to the restriction that the present value of consumption is no greater than the present value of income. The models then assess how tax policies can alter the rewards to saving and working, thereby distorting intertemporal choices about consumption and work effort. But models with an overall lifetime budget constraint ignore the many restrictions on individuals' ability to shift income in a world of capital market imperfections, restrictions that substantially affect those intertemporal choices. ${ }^{2}$ Taking into account the effect of liquidity constraints affects the calculation of the welfare costs of taxation substantially; prevailing arguments, based on "perfect market" models, against capital taxation or progressive income taxation and in favor of wage and consumption taxation must be substantially muted and often reversed. ${ }^{3}$

The second issue that we examine is the importance of liquidity constraints for the debate over the impact of temporary tax cuts financed by debt. We show that liquidity-constraint considerations are quantitatively more important than the frequently discussed "finite-horizon" considerations that focus on how debt shifts the tax burden onto future generations. We also find that when both considerations are incorporated

1. See, for example, Lawrence H. Summers, "Capital Taxation and Accumulation in a Life Cycle Growth Model," American Economic Review, vol. 71 (September 1981), pp. 533-44; Alan J. Auerbach and Laurence J. Kotlikoff, "National Savings, Economic Welfare, and the Structure of Taxation," in Martin Feldstein, ed., Behavioral Simulation Methods in Tax Policy Analysis (University of Chicago Press, 1983), pp. 459-93; Alan J. Auerbach, Laurence J. Kotlikoff, and Jonathan Skinner, "The Efficiency Gains from Dynamic Tax Reform," International Economic Review, vol. 24 (February 1983), pp. 81-100; and E. John Driffill and Harvey S. Rosen, "Taxation and Excess Burden: A Life Cycle Perspective," International Economic Review, vol. 24 (October 1983), pp. 671-83.

2. See, for example, the earlier analysis by James Tobin and Walter Dolde, "Wealth, Liquidity and Consumption," in Consumer Spending and Monetary Policy: The Linkages (Federal Reserve Bank of Boston, 1971), pp. 99-146.

3. This issue is discussed with respect to the social security payroll tax in R. Glenn Hubbard and Kenneth L. Judd, "Social Security and Individual Welfare: Precautionary Saving, Liquidity Constraints, and the Payroll Tax," Working Paper 1736 (National Bureau of Economic Research, October 1985). 
into the consumption function, debt-financed tax cuts of the type observed in the post-World War II era do not substantially alter aggregate consumption.

In this light, the plan of the paper is as follows. First, we elaborate on the potential macroeconomic importance of liquidity constraints and their role in tax policy analysis in life-cycle consumption models. We then develop a simple life-cycle model to examine the effects of liquidity constraints on measures of national saving and individual welfare. We focus on the life-cycle model because of its easy applicability to fiscal policy analysis. Use of this model introduces no bias a priori in our examination of the effects of liquidity constraints, since the life-cycle model under rational expectations and with perfect capital markets offers fiscal policy little scope in influencing consumption. We consider three major applications: the relative welfare costs of capital versus labor income taxation, effects of progressive versus proportional income taxation, and effects of temporary tax changes on consumption.

\section{Liquidity Constraints and Consumption}

The effect of liquidity constraints, defined in various ways, on consumer spending has been considered in many studies. ${ }^{4}$ In response to Robert Lucas's critique of econometric policy evaluation, Robert Hall proposed the "Euler equation" approach to testing the sensitivity of consumption to current income changes. ${ }^{5}$ In Hall's model, to be

4. For a general discussion, see Tobin and Dolde, "Wealth, Liquidity and Consumption"; Alan S. Blinder, "Intergenerational Transfers and Life Cycle Consumption," American Economic Review, vol. 66 (May 1976, Papers and Proceedings, 1975), pp. 87-93; Walter Dolde, "Capital Markets and the Short Run Behavior of Life Cycle Savers," Journal of Finance, vol. 33 (May 1978), pp. 413-28; and Fumio Hayashi, "Tests for Liquidity Constraints: A Critical Survey," Working Paper 1720 (National Bureau of Economic Research, October 1985).

5. Robert E. Lucas, Jr., "Econometric Policy Evaluation: A Critique," in Karl Brunner and Allan H. Meltzer, eds., The Phillips Curve and Labor Markets, CarnegieRochester Conference Series on Public Policy, vol. 1 (Amsterdam: North-Holland, 1976), pp. 19-46; Robert E. Hall, "Stochastic Implications of the Life Cycle-Permanent Income Hypothesis: Theory and Evidence," Journal of Political Economy, vol. 86 (December 1978), pp. 971-87. For a discussion of econometric problems (in particular, aggregation issues) with Euler equation methods, see Angus S. Deaton, "Life-Cycle Models of Consumption: Is the Evidence Consistent with the Theory?" (Princeton University, July 1985). 
consistent with the permanent-income hypothesis under rational expectations (with no borrowing restrictions), conditional on lagged consumption, expected consumption should be independent of other lagged information. Other empirical studies find consumer spending to be sensitive to income changes. ${ }^{6}$ Findings of excess sensitivity of consumption to changes in disposable income are corroborated in a study of food expenditures by Hall and Frederic Mishkin. ${ }^{7}$

Our analysis is predicated on the idea that this excess sensitivity can be traced to the operation of liquidity constraints, the aggregate importance of which for the United States is amply illustrated by historical evidence. Bradford DeLong and Lawrence Summers note that from 1899 to 1916 , "essentially all consumption was done by liquidityconstrained consumers." 8 Their findings for the entire pre-World War II period broadly support this conclusion and suggest the possibility, which we consider in our simulation exercises, that forced lifetime saving (that is, underconsumption) by consumers who are liquidity constrained may be an important component of total saving. For example, Alan Auerbach and Laurence Kotlikoff note that personal saving rates in the United States exceeded 20 percent during the 1880 s-before the availability of consumer credit and the pursuit of stabilization policy. ${ }^{9}$

Fumio Hayashi finds that liquidity-constrained consumers accounted for approximately 20 percent of all consumption in post-World War II United States. ${ }^{10}$ In a separate effort using microeconomic data, Hayashi

6. Marjorie A. Flavin, "The Adjustment of Consumption to Changing Expectations about Future Income,' Journal of Political Economy, vol. 89 (October 1981), pp. 9741009; Fumio Hayashi, "The Permanent Income Hypothesis: Estimation and Testing by Instrumental Variables," Journal of Political Economy, vol. 90 (October 1982), pp. 895916; Lars Peter Hansen and Kenneth J. Singleton, "Generalized Instrumental Variables Estimation of Nonlinear Rational Expectations Models," Econometrica, vol. 50 (September 1982), pp. 1269-86; Alan S. Blinder and Angus Deaton, "The Time Series Consumption Function Revisited," BPEA, 2:1985, pp. 465-511.

7. Robert E. Hall and Frederic S. Mishkin, "The Sensitivity of Consumption to Transitory Income: Estimates from Panel Data on Households," Econometrica, vol. 50 (March 1982), pp. 461-81.

8. J. Bradford DeLong and Lawrence H. Summers, "The Changing Cyclical Variability of Economic Activity in the United States," in Robert J. Gordon, ed., The American Business Cycle: Continuity and Change (University of Chicago Press, 1986).

9. Auerbach and Kotlikoff, "National Savings."

10. Hayashi, "The Permanent Income Hypothesis." Moreover, using the NIPA definition of personal consumption expenditures, which excludes service flows from consumer durables and includes expenditures on consumer durables, he finds that 96 
also notes that the relationship between consumption and income movements differs significantly for "high saving" and "low saving", families. ${ }^{11}$ Ben Bernanke finds no evidence that the permanent-income hypothesis needs to be amended for liquidity constraints in his examination of individual expenditures on automobiles. ${ }^{12}$ Automobile loans, however, are self-collateralized, and our focus is on the unavailability of noncollateralized consumption loans. Marjorie Flavin finds that the estimate of the marginal propensity to consume is affected dramatically by the inclusion of proxies for liquidity constraints. ${ }^{13}$ In her econometric work, Flavin uses the aggregate unemployment rate as a proxy for liquidity constraints and tests "myopia" and liquidity-constraint explanations of the excess sensitivity findings. She reports that the estimated marginal propensity to consume out of transitory income is explained almost entirely by proxies for liquidity constraints.

We analyze the liquidity constraint arising from a nonnegativity constraint on net worth. ${ }^{14}$ That is, consumers are not permitted to borrow against income to be received in the future; current consumption is

percent of personal consumption expenditures could be due to liquidity-constrained households.

11. Fumio Hayashi, "The Effect of Liquidity Constraints on Consumption: A CrossSectional Analysis," Quarterly Journal of Economics, vol. 100 (February 1985), pp. 183-206. David Runkle and Stephen Zeldes also find that the sensitivity of consumption to changes in income depends on household wealth. See David Runkle, "Liquidity Constraints and the Permanent Income Hypothesis: Evidence from Panel Data" (Brown University, 1983); Stephen Zeldes, "Consumption and Liquidity Constraints: An Empirical Investigation" (Wharton School, University of Pennsylvania, 1985).

12. Ben S. Bernanke, "Permanent Income, Liquidity, and Expenditure on Automobiles: Evidence from Panel Data,' Quarterly Journal of Economics, vol. 99 (August 1984), pp. 587-614.

13. Marjorie Flavin, "Excess Sensitivity of Consumption to Current Income: Liquidity Constraints or Myopia?" Working Paper 1341 (National Bureau of Economic Research, May 1984).

14. This assumption is also used in the tax analysis work of Feldstein and Daniel Feenberg. See also the macroeconomic model of Carl Walsh and the analyses of the social security payroll tax by Hubbard and Judd. Martin Feldstein and Daniel R. Feenberg, "Alternative Tax Rules and Personal Saving Incentives: Microeconomic Data and Behavioral Simulations," in Feldstein, ed., Behavioral Simulation Methods, pp. 173-210: Carl E. Walsh, "Borrowing Restrictions and Wealth Constraints: Implications for Aggregate Consumption," Working Paper 1629 (National Bureau of Economic Research, June 1985); R. Glenn Hubbard, "Social Security, Liquidity Constraints, and Pre-Retirement Consumption," Southern Economic Journal, vol. 52 (October 1985), pp. 471-83; Hubbard and Judd, "Social Security." 
limited by current resources. For consumers who cannot finance their desired level of consumption with current wealth, consumption is responsive to changes, even anticipated changes, in disposable income. This particular notion of liquidity constraints does not reflect problems of imperfect information in loan markets; indeed, we will be working with earnings profiles that are known to consumers with perfect certainty. ${ }^{15}$ Rather, we appeal to large transactions costs and the possibility of bankruptcy in explaining borrowing restrictions. ${ }^{16}$

If anything, this characterization of restrictions on borrowing understates the importance of liquidity constraints in the real world. In the analytical approach we adopt here, only net consumption loans are disallowed. Real-world restrictions besides the need for collateral (for example, minimum-income requirements for debt service) would strengthen our results. Our constraint does not rule out collateralized loans for such durables as homes or cars. ${ }^{17}$ Consumption loans do not loom large in U.S. consumer credit; in 1985, the volume of household borrowing for unsecured installment loans totaled only $\$ 21.9$ billion; for new automobile loans, $\$ 37.8$ billion; and for new home mortgage loans, $\$ 152.8$ billion. ${ }^{18}$ Our nonnegativity constraint on net wealth is thus broadly consistent with this low level of unsecured borrowing as well as with the empirical work discussed above.

15. For a discussion of information problems, see Joseph E. Stiglitz and Andrew Weiss, "Credit Rationing in Markets with Imperfect Information," American Economic Review, vol. 71 (June 1981), pp. 393-410; and Charles W. Calomiris and R. Glenn Hubbard, "Price Flexibility, Credit Rationing, and Economic Fluctuations: Evidence from the U.S., 1879-1914," Working Paper 1767 (National Bureau of Economic Research, October 1985).

16. These distinctions can be important. For example, Hayashi discusses conditions under which excess sensitivity traceable to liquidity constraints from imperfect information in the loan market is not exploitable by stabilization policy; see Hayashi, "Tests for Liquidity Constraints." The form of borrowing restrictions we stress will be exploitable. Note that what is important is not so much that current resources are low absolutely but that they are low relative to lifetime resources. Some households may be liquidity constrained, in the sense of being unable to finance desired consumption, because of anticipated bequests. For a discussion of this point, see Blinder, "Intergenerational Transfers"; and Hubbard and Judd, "Social Security."

17. Even for collateralized loans, large spreads between borrowing and lending rates exist. According to the Federal Reserve Bulletin, the average interest rate on twentyfour-month personal loans in 1982, 1983, and 1984 was $18.65,16.50$, and 16.47 percent, respectively, while the yield on two-year U.S. Treasury notes over the same period was $12.80,10.21$, and 11.65 percent, respectively.

18. Federal Reserve Bulletin, May 1986, tables A40 and A42. 
Figure 1. Consumption and Earnings over the Life Cycle

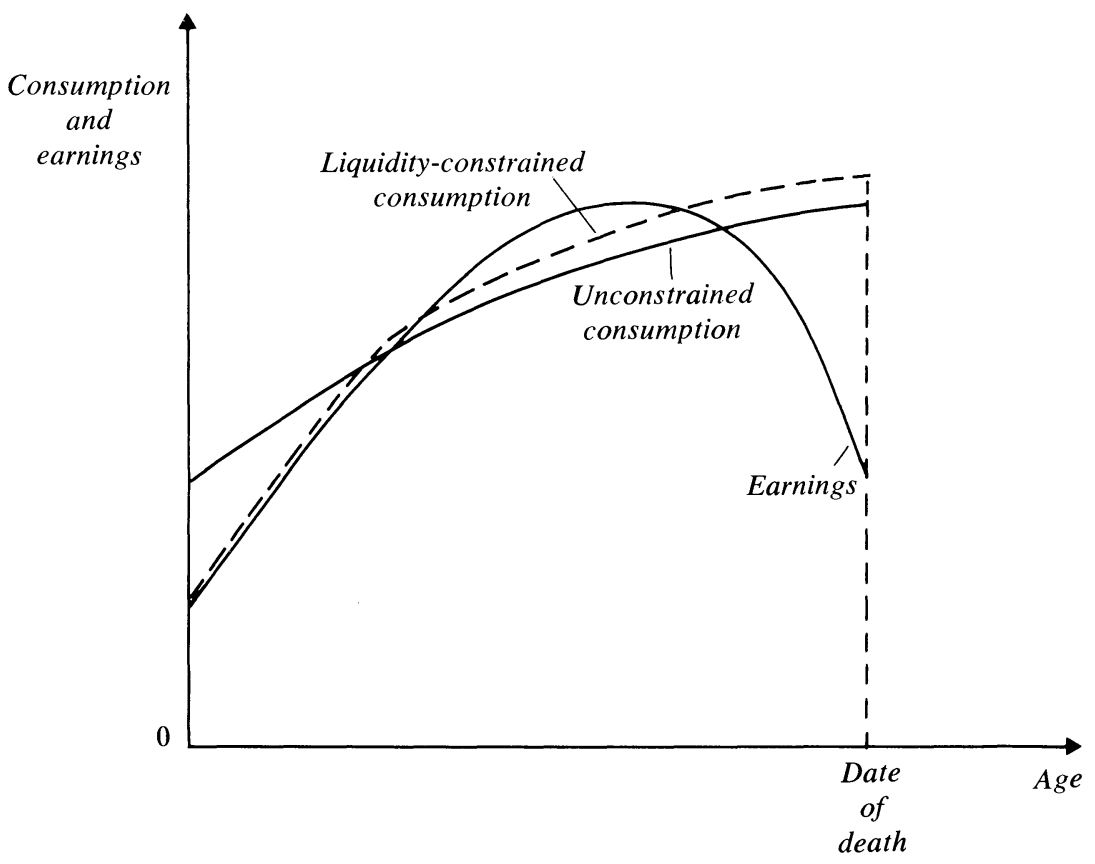

The impact of liquidity constraints on consumption is most easily illustrated in a simple life-cycle model, in which individuals make consumption and saving decisions over a known lifetime. ${ }^{19}$ In such an unconstrained model, consumption typically exceeds earnings in youth, while earnings exceed consumption in middle age and then decline in retirement, as illustrated by the solid lines in figure 1 . The corresponding wealth-age profile is illustrated by the solid line in figure 2 , where net worth is zero at death.

In the presence of a nonnegativity constraint on net worth, however, consumption cannot exceed current resources in any period. As shown in the dotted line in figure 1, consumption tracks earnings during youth, when the constraint is binding, then increases relative to the perfectcapital-markets profile thereafter. This pattern is also reflected in the individual wealth-age profile in figure 2 . Lifetime utility from consump-

19. We take up the issue of uncertainty over life expectancy with qualitatively similar results in an earlier paper. Hubbard and Judd, "Social Security." 
Figure 2. Net Worth over the Life Cycle

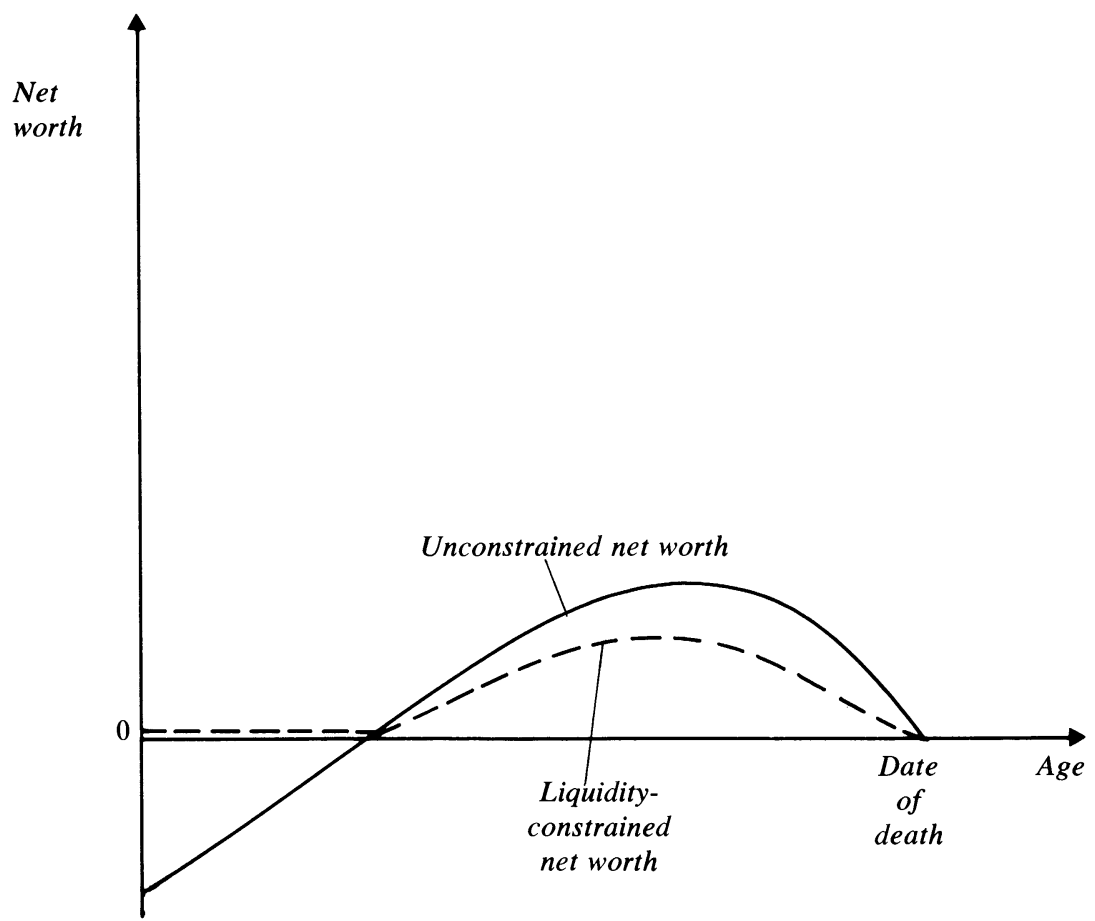

tion is reduced by the constraint, with the magnitude of the reduction increasing the flatter is the desired consumption profile (or for an isoelastic utility function, the lower is the intertemporal elasticity of substitution in consumption). To the extent that desired consumption is even more age-related-increasing, for example, in middle age as children are being reared - the same intuition applies. The constraint will be less binding in youth, more binding in middle age. ${ }^{20}$ Tax policies that depress consumers' net earnings during their constrained periods will depress consumption dollar for dollar.

20. For more detailed analyses, see James Tobin, "Life Cycle Saving and Balanced Growth," in William J. Fellner and others, eds., Ten Economic Studies in the Tradition of Irving Fisher (John Wiley and Sons, 1967), pp. 231-56; Tobin and Dolde, "Wealth, Liquidity and Consumption"; William C. Brainard, "Private and Social Risk and Return to Education," in Keith G. Lumsden, Efficiency in Universities: The La Paz Papers (Amsterdam: Elsevier Scientific Publishing Co., 1974), pp. 241-65. 
Many households are likely to experience binding liquidity constraints of this type..$^{21}$ In 1983 a significant fraction of a sample of U.S. households held financial assets insufficient to insulate consumption from even modest declines in earnings in the presence of restrictions on borrowing against future earnings. For example, median holdings of financial assets in the sample were only $\$ 3,500 .{ }^{22}$ As table 1 shows, both low-income and young households had especially low levels of financial assets. A nontrivial portion of households whose head was under thirty-five years of age or who earned less than $\$ 15,000$ a year held no financial assets whatsoever. Moreover, because financial assets in the table are defined to include Individual Retirement Account and Keogh balances, the totals overstate funds easily available to finance consumption.

We do not take into account the ability of liquidity-constrained consumers to borrow against net nonfinancial assets such as equity in homes, partly because large-scale tapping of housing equity to finance consumption arose only recently and in response to capital gains on housing during the 1970s. In any event, as indicated in table 2, net worth, including home equity, is quite low for young households, most of which do not own homes.

We also ignore the possibility of substantial inter vivos gifts from parents to young adults to relax liquidity constraints. To affect our results materially, such gifts would have to include not only such "investments" as college tuition payments, but also contributions to income during periods of low earnings. Moreover, the provision of inter vivos gifts to children may exacerbate liquidity constraints on the parents' consumption, a point discussed in more detail later.

Consistent with these observations, the source of liquidity constraints modeled here is the excess of desired consumption over current earnings for young, low-income households. ${ }^{23}$ Even if future earnings are certain,

21. For a discussion of the relevance of the existence of a sufficient number of households with "too little" net worth for estimating saving equations with crosssectional data, see M. A. King and L.-D. L. Dicks-Mireaux, "Asset Holdings and the Life Cycle," Economic Journal, vol. 92 (June 1982), pp. 247-67; R. Glenn Hubbard, "Do IRAs and Keoghs Increase Saving?" National Tax Journal, vol. 37 (March 1984), pp. 43-54; and Hubbard, "Pension Wealth and Individual Saving: Some New Evidence," Journal of Money, Credit, and Banking, vol. 18, forthcoming.

22. "Survey of Consumer Finances, 1983," Federal Reserve Bulletin, vol. 70 (September 1984), table 10, p. 686.

23. See also Hayashi, "The Effect of Liquidity Constraints." 
Table 1. Financial Assets of Households, by Income and Age of Head of Household, $1^{1983}{ }^{\text {a }}$

Dollars unless otherwise specified

\begin{tabular}{|c|c|c|c|c|c|}
\hline \multirow[b]{2}{*}{ Item } & \multirow{2}{*}{$\begin{array}{l}\text { Percent owning } \\
\text { financial assets }\end{array}$} & \multicolumn{2}{|c|}{ Liquid assets } & \multicolumn{2}{|c|}{$\begin{array}{l}\text { Total financial } \\
\text { assets }\end{array}$} \\
\hline & & Mean & Median & Mean & Median \\
\hline \multicolumn{6}{|c|}{ Household income } \\
\hline Less than 5,000 & 57 & 2,177 & 500 & 3,254 & 513 \\
\hline $5,000-7,499$ & 70 & 3,663 & 1,000 & 4,296 & 1,000 \\
\hline $7,500-9,999$ & 75 & 5,378 & 800 & 6,114 & 848 \\
\hline $10,000-14,999$ & 87 & 9,549 & 1,719 & 11,619 & 2,205 \\
\hline $15,000-19,999$ & 93 & 9,130 & 1,513 & 12,021 & 1,780 \\
\hline $20,000-24,999$ & 95 & 11,365 & 2,105 & 14,078 & 2,385 \\
\hline $25,000-29,999$ & 97 & 12,509 & 2,798 & 18,539 & 3,349 \\
\hline $30,000-39,999$ & 99 & 17,783 & 4,717 & 22,752 & 5,950 \\
\hline $40,000-49,999$ & 99 & 16,285 & 7,828 & 32,342 & 10,631 \\
\hline 50,000 or more & 99 & 45,541 & 19,886 & 125,131 & 31,658 \\
\hline \multicolumn{6}{|c|}{ Age of head of household } \\
\hline Under 25 & 81 & 1,972 & 600 & 2,646 & 746 \\
\hline $25-34$ & 87 & 4,274 & 1,203 & 7,963 & 1,514 \\
\hline $35-44$ & 91 & 8,911 & 3,000 & 14,414 & 3,750 \\
\hline $45-54$ & 89 & 14,826 & 3,308 & 23,009 & 4,131 \\
\hline $55-64$ & 91 & 25,439 & 7,425 & 54,951 & 9,338 \\
\hline $65-74$ & 88 & 30,666 & 9,676 & 65,339 & 11,400 \\
\hline 75 and over & 86 & 26,481 & 7,885 & 37,060 & 10,350 \\
\hline
\end{tabular}

Source: "Survey of Consumer Finances, 1983," Federal Reserve Bulletin, vol. 70 (September 1984), p. 686, table 10.

a. Liquid assets include checking and savings accounts, money-market funds, IRA and Keogh balances, savings bonds, and certificates of deposit. Financial assets include liquid assets and holdings of stocks, bonds, and trusts.

the presence of borrowing restrictions in youth will cause the consumption profile to differ from its no-restrictions counterpart. Uncertain streams of earnings can also lead to liquidity constraints with a nonnegativity constraint on resources available for current consumption. ${ }^{24}$ Adding this complexity would not alter our qualitative results; indeed, it would strengthen the importance of liquidity constraints in accounting for national saving. ${ }^{25}$

24. Robert Barsky, Gregory Mankiw, and Stephen Zeldes analyze the nonneutrality of temporary tax cuts in this case. Hal Varian discusses the issue in terms of redistributive tax policy as social insurance. Robert B. Barsky, N. Gregory Mankiw, and Stephen P. Zeldes, "Ricardian Consumers with Keynesian Propensities," Working Paper 1400 (National Bureau of Economic Research, July 1984); Hal R. Varian, "Redistributive Taxation as Social Insurance," Journal of Public Economics, vol. 14 (August 1980), pp. 49-68.

25. In an econometric analysis, Jonathan Skinner does not find a significant effect 
Table 2. Homeownership and Total Net Worth of Households, by Age of Head of Household, 1983

Dollars unless otherwise specified

\begin{tabular}{lcc}
\hline $\begin{array}{l}\text { Age of head } \\
\text { of household }\end{array}$ & $\begin{array}{c}\text { Median total } \\
\text { net } \text { worth }\end{array}$ & $\begin{array}{c}\text { Percent owning } \\
\text { home }\end{array}$ \\
\hline Under 25 & 5 & n.a. \\
Under 35 & n.a. & 34 \\
$25-34$ & 3,654 & n.a. \\
$35-44$ & 28,721 & 66 \\
$45-54$ & 43,797 & 75 \\
$55-64$ & 55,587 & 73 \\
$65-74$ & 50,181 & n.a. \\
65 and over & n.a. & 70 \\
75 and over & 35,939 & n.a. \\
\hline
\end{tabular}

Sources: Information on median total net worth is from "Survey of Consumer Finances, 1983: A Second Report," Federal Reserve Bulletin, vol. 70 (December 1984), p. 863, table 7. Information on percent owning home is from "Survey of Consumer Finances, 1983," Federal Reserve Bulletin, vol. 70 (September 1984), p. 683, table 5.

n.a. Not available.

a. Homeownership information is reported for ages 35 and under and 65 and over, rather than for the more disaggregated categories.

\section{Liquidity Constraints and Consumption in the Life-Cycle Model}

Most questions of fiscal policy or tax reform are best suited to multiperiod models that consider long-run effects of reforms, either for individuals or for the economy. Even two-period models can deliver surprising results about the effect of tax policy changes on such variables as saving. ${ }^{26}$

\section{THE LIFE-CYCLE MODEL AND TAX POLICY ANALYSIS}

It is not surprising that the life-cycle model of consumption has been the workhorse of many analyses of the effects of tax changes on consumption and welfare..$^{27}$ The model provides a realistic number of periods in an individual's life to permit consideration of the effect of

of "earnings uncertainty" on individual saving. We discuss this point again in the context of our simulation exercises. Jonathan Skinner, "Risky Income and Life Cycle Consumption" (University of Virginia, July 1985).

26. See Martin Feldstein, "The Welfare Cost of Capital Income Taxation," Journal of Political Economy, vol. 86 (April 1978, part 2), pp. S29-S51.

27. For a description of the model, see Franco Modigliani and Richard Brumberg, "Utility Analysis and the Consumption Function: An Interpretation of Cross-Section Data," in Kenneth K. Kurihara, ed., Post-Keynesian Economics (Rutgers University 
even temporary policy changes on lifetime consumption and welfare. It is extremely valuable as an analytical tool because it does not rely on ad hoc rules of behavior and is consistent with basic demand and supply theory and rational expectations methodology. The life-cycle framework has been used in the construction of dynamic general equilibrium models that permit comparison of steady states of different policy regimes. ${ }^{28}$

While the life-cycle model provides a theoretically consistent and logical framework for an examination of policy-induced changes in consumption, it is not without its critics. At the theoretical level, it has been argued that the model requires consumers to be both "not forwardlooking enough" and "too forward-looking." In one case, critics assert that consumers are much more myopic than the life-cycle model would allow, that they might be guided, for example, by rule-of-thumb saving behavior ${ }^{29}$ It is not obvious what effect tax policy would have in such a world. In the alternative case, most closely associated with Robert Barro, critics argue that if consumers consider their heirs when making their own consumption decisions, the relevant optimizing horizon may be infinite, and the capital stock would not arise out of a mismatching of earnings and desired consumption over individuals' lives. ${ }^{30}$

The life-cycle model's predictions have also been criticized in empirical studies. For example, some studies of wealth profiles over time find a significant number of individuals or households with "too little wealth." 31

Press, 1954), pp. 388-436; and Albert Ando and Franco Modigliani, "The 'Life Cycle' Hypothesis of Saving: Aggregate Implications and Tests," American Economic Review, vol. 53 (March 1963), pp. 55-84. For a survey of applications to fiscal policy issues, see Laurence J. Kotlikoff, “Taxation and Savings: A Neoclassical Perspective,'” Journal of Economic Literature, vol. 22 (December 1984), pp. 1576-1629.

28. See Summers, "Capital Taxation"; Auerbach, Kotlikoff, and Skinner, "The Efficiency Gains"; and Hubbard and Judd, "Social Security."

29. Richard H. Thaler and H. M. Shefrin, "An Economic Theory of Self-Control," Journal of Political Economy, vol. 89 (April 1981), pp. 392-406.

30. Robert J. Barro, “Are Government Bonds Net Wealth?' Journal of Political Economy, vol. 82 (November-December 1974), pp. 1095-1117. For an interesting comparison of predictions of life-cycle and infinite-horizon models, see Michael $\mathrm{J}$. Boskin and Laurence J. Kotlikoff, "Public Debt and U.S. Saving: A New Test of the Neutrality Hypothesis," Working Paper 1646 (National Bureau of Economic Research, June 1985).

31. See the study for Canada by King and Dicks-Mireaux, and for the United States by Hubbard. King and Dicks-Mireaux, "Asset Holdings"; Hubbard, "Do IRAs Increase Saving?" 
In addition, econometric studies typically find lower dissaving rates among the retired elderly than the theory would predict, though James Davies and Hubbard have offered uncertainty about life expectancy and the fear of living too long as plausible explanations within the life-cycle framework. ${ }^{32}$ Perhaps most challenging to applications of the basic model is the claim by Laurence Kotlikoff and Lawrence Summers that life-cycle saving as they define it can explain only a small portion of the capital stock in the United States, with the clear implication that models emphasizing intergenerational transfers as the dominant factor in saving decisions deserve more attention. ${ }^{33}$

These empirical questions about the life-cycle model do not necessarily refute the basic insight of the theory, that consumers are forward looking in their behavior and optimize over a long (lifetime) horizon. Here we maintain that insight and focus on the implications of liquidity constraints for analyses of the impact of tax changes or tax reform on national saving and individual welfare. The specification of a lifetime budget constraint in standard uses of the life-cycle model is not an accurate representation of restrictions on consumption smoothing when capital markets are characterized by collateral restrictions, differences in borrowing and lending rates, and credit rationing. The central issue within the life-cycle framework is as follows. Hump-shaped lifetime earnings profiles rising toward middle age then leveling off and declining in old age imply that individuals will want to consume more than their current resources allow when young. ${ }^{34}$ They cannot do so if liquidity constraints are binding.

32. For studies of dissaving among the elderly, see Thad W. Mirer, "The WealthAge Relation among the Aged," American Economic Review, vol. 69 (June 1979), pp. 435-43; King and Dicks-Mireaux, "Asset Holdings"'; and Hubbard, "Pension Wealth." For explanations of the low dissaving rate, see James B. Davies, "Uncertain Lifetime, Consumption, and Dissaving in Retirement," Journal of Political Economy, vol. 89 (June 1981), pp. 561-77; and R. Glenn Hubbard, “' 'Precautionary' Saving Revisited: Social Security, Individual Welfare and the Capital Stock,' Working Paper 1430 (National Bureau of Economic Research, August 1984).

33. Laurence J. Kotlikoff and Lawrence H. Summers, "The Role of Intergenerational Transfers in Aggregate Capital Accumulation," Journal of Political Economy, vol. 89 (August 1981), pp. 706-32. The potential role of precautionary saving in accounting for this discrepancy is emphasized by Hubbard and Judd in "Social Security."

34. See Davies, "Uncertain Lifetime"; and Finis Welch, "Effects of Cohort Size on Earnings: The Baby Boom Babies' Financial Bust," Journal of Political Economy, vol. 87 (October 1979, part 2), pp. S65-S97. 


\section{SIMULATING THE IMPORTANCE OF LIQUIDITY CONSTRAINTS}

To simulate the effects of alternative tax and fiscal policies on consumption, we make use of a life-cycle model in which no bequests are desired and individuals consume so as to maximize an intertemporal utility function subject to a lifetime budget constraint. Individuals live for $T$ years, working only for the first $R$ years; the retirement age of $R$ is taken as exogenous, and, for the moment, assume that labor is supplied inelastically. (We use a model with elastic labor supply in all simulations; see the discussion of the full model in appendix A.) Model simulations begin at the commencement of individuals' working lives, assumed to be age twenty. Retirement occurs after forty-five years of work; death occurs ten years later.

The addition of substantial bequests would complicate the model..$^{35}$ Bequests can be either planned or "accidental." The latter occur when individuals who have saved to insure against long life die prematurely and with positive wealth. In the context of accidental bequests generated by precautionary saving, the effects of liquidity constraints remain important. ${ }^{36}$ In fact, because many liquidity-constrained individuals are effectively constrained only early in life, to the extent that accidental bequests are received relatively late in life, our conclusions about the importance of liquidity constraints are strengthened, since desired consumption in youth would be further increased relative to current resources.

Nor would planned bequests seriously weaken our analysis. If an individual plans to leave a bequest to his child, his desired lifetime consumption is reduced. However, if he himself receives a bequest from a parent, that bequest could be used to finance his bequest to his child. As long as the bequest he receives from his parent arrives after his constrained periods and he plans on leaving a comparably sized bequest

35. Michael Hurd finds essentially no bequest motive evident in the saving behavior of households in the Retirement History Survey, concluding that bequests are much more likely to be of the "accidental" variety attributable to lifetime uncertainty. Michael D. Hurd, "Savings and Bequests," Working Paper 1826 (National Bureau of Economic Research, January 1986).

36. See the analysis of liquidity constraints and precautionary saving in Hubbard and Judd, "Social Security." 
to his child, a natural steady-state assumption, his consumption path is financed by his earnings, and bequests received and given are not important for consumption decisions. Therefore, ignoring bequests does not seriously reduce the plausibility of our analysis for the issues we examine below.

Assuming that utility is additively separable across periods, individuals maximize

$$
\int_{0}^{T} U(c) e^{-\rho t} d t
$$

subject to

$$
\dot{A}=\left(1-\tau_{L}\right) E+\left(1-\tau_{K}\right) r A-c, A(0)=A(T)=0,
$$

where $c, \rho$, and $r$ represent consumption, the (constant) subjective discount rate, and the interest rate, respectively. The coefficients $\tau_{L}$ and $\tau_{K}$ denote tax rates on labor and capital income, respectively; $A$ represents the stock of accumulated assets. A dot over a variable denotes a time rate of change. The income stream, $E$, represents labor earnings.

For simplicity, assuming that the utility function is of the isoelastic form, we can rewrite equation 1 as

$$
\max \int_{0}^{T} \frac{1}{1-\beta^{-1}} c^{1-\beta^{-1}} e^{-\rho t} d t,
$$

where $\beta$ measures the intertemporal elasticity of substitution in consumption.

If $\lambda$ denotes the marginal utility of consumption and $c(\lambda)$ is defined as consumption corresponding to $\lambda$, the differential equations describing the time paths of consumption and wealth accumulation are given by

$$
\dot{\lambda}=\left[\rho-\left(1-\tau_{K}\right)-r\right] \lambda,
$$

and

$$
\dot{A}=\left(1-\tau_{K}\right) r A+\left(1-\tau_{L}\right) E-c(\lambda),
$$

together with the boundary conditions $A(0)=A(T)=0$.

In the absence of borrowing restrictions, the capital stock will be a 
function of underlying parameter values, the age distribution of the population, and the shapes of individual earnings profiles. In the basic life-cycle model, individual savings profiles are expected to be humpshaped, with borrowing by young people, substantial asset accumulation by those in middle age, and dissaving by the elderly. Within this framework, "tax reforms," either changes in tax rates or shifts in relative reliance on different tax bases, have real effects only to the extent that they alter steady-state factor prices.

These results will be qualified in the presence of borrowing restrictions. It is here that the choice of pretax earnings profiles for simulation exercises is particularly relevant. We chose the profile used by Davies. ${ }^{37}$ By using an average earnings profile, we are ignoring individual-specific fluctuations in earnings. Since the marginal loss due to a tighter liquidity constraint is negligible if the constraint is slack and greater when the constraint is binding, losses due to the liquidity constraint are convex in the tightness of the constraint. Using the average earnings pattern means that losses are underestimated, since the distribution of earnings patterns would include some with much tighter constraints as well as some with looser constraints.

When we impose the constraint that net worth must be nonnegative at all times, we substantially change the nature of the consumer's optimization problem. The budget constraint in equation 2 becomes

$$
\dot{A}=\left(1-\tau_{L}\right) E+\left(1-\tau_{K}\right) r A-c, A(t) \geqslant 0 .
$$

The first-order conditions must be altered to take into account this state constraint.$^{38}$ The new arbitrage conditions become

$$
\begin{aligned}
& \dot{\lambda}=\left[\rho-\left(1-\tau_{K}\right) r\right] \lambda, \text { if } A>0 \text { or } \lambda>U^{\prime}\left[\left(1-\tau_{L}\right) E\right], \\
& \lambda=U^{\prime}\left[\left(1-\tau_{L}\right) E\right], \text { if } A=0 \text { and } \lambda \leqslant U^{\prime}\left[\left(1-\tau_{L}\right) E\right],
\end{aligned}
$$

where $\lambda$ is continuous. Assets obey

37. Davies, "Uncertain Lifetime." That is, as in Davies (p. 572), the lifetime path of mean noninvestment income $E$ is approximated by a fourth-order polynomial:

$$
E(t)=-36,999.4+3520.22 t-101.878 t^{2}+1.34816 t^{3}-0.00706233 t^{4} .
$$

38. For a discussion of such problems, see Morton I. Kamien and Nancy L. Schwartz, Dynamic Optimization: The Calculus of Variations and Optimal Control in Economics and Management (Amsterdam: North-Holland, 1982). 


$$
\begin{aligned}
& \dot{A}=0, \text { if } A=0 \text { and } \lambda \leqslant U^{\prime}\left[\left(1-\tau_{L}\right) E\right], \\
& \dot{A}=\left(1-\tau_{K}\right) r A+\left(1-\tau_{L}\right) E-c(\lambda) \text { otherwise. }
\end{aligned}
$$

If assets are positive or if earnings exceed consumption, then equation 2 still holds. Otherwise, consumption is limited to current earnings, and the consumer's optimization problem is divided into constrained and unconstrained intervals; equation $4 \mathrm{~b}^{\prime}$ governs how these intervals meet. At the point when $A \geqslant 0$ becomes binding, it imposes the necessary tangency relation between $A$ and the constraint. The reason is that if $A$ is falling when the liquidity constraint begins to bind, consumption must fall discontinuously, an unlikely event, since the consumer could have smoothed consumption by slowing the decumulation.

Aggregate consumption is determined in the model by summing over the individual consumption of those alive at a given time. That is, consumption of individuals at each age is determined, with the relative number of individuals at each age depending on the rate of growth of population. Aggregate asset stocks are constructed similarly. To obtain estimates of the importance of liquidity constraints for steady-state measures of the aggregate capital stock, we initially allow for variable factor prices. We assume that output is produced according to a CobbDouglas production function in capital and labor, with a capital share equal to $\alpha$. Factor markets are assumed to be competitive, so that capital and labor are paid their marginal products. That is, the gross interest rate, $r$, and base wage rate, $w$, satisfy

$$
\begin{aligned}
& r=\alpha k^{\alpha-1}, \text { and } \\
& w=(1-\alpha) k^{\alpha},
\end{aligned}
$$

where $k$ represents the capital-labor ratio.

Within this framework, the steady state can be solved as follows. A guess is made for $k$. Solutions for $r$ and $w$ are then generated from the marginal productivity conditions to produce individual consumption and wealth profiles. The resulting aggregate consumption and capital stock are compared with the initial guess, and iteration proceeds until convergence is reached.

In table 3, we present findings on the effects of borrowing restrictions on the capital stock and individual welfare when $\alpha=0.3$. The discount rate was chosen to be 1.5 percent, and population growth was assumed 
Table 3. Importance of Liquidity Constraints for Steady-State Values of National Saving ${ }^{a}$

\begin{tabular}{|c|c|c|c|c|c|}
\hline \multirow{2}{*}{$\begin{array}{c}\text { Elasticity of } \\
\text { substitution } \\
\text { in } \\
\text { consumption } \\
(\beta)^{\mathrm{b}}\end{array}$} & \multicolumn{2}{|c|}{ Capital-income ratio } & \multirow{2}{*}{$\begin{array}{l}\text { Number of } \\
\text { periods } \\
\text { constrained }\end{array}$} & \multirow{2}{*}{$\begin{array}{l}\text { Percent of } \\
\text { population } \\
\text { constrained }\end{array}$} & \multirow{2}{*}{$\begin{array}{c}\text { Percent of } \\
\text { income held } \\
\text { by } \\
\text { constrained } \\
\text { consumers }\end{array}$} \\
\hline & $\begin{array}{l}\text { Uncon- } \\
\text { strained }\end{array}$ & Constrained & & & \\
\hline 1.10 & 4.40 & 4.43 & 4 & 7.3 & 2.7 \\
\hline 0.50 & 2.79 & 3.26 & 6 & 12.0 & 5.5 \\
\hline 0.25 & 1.64 & 2.21 & 9 & 19.0 & 10.8 \\
\hline 0.20 & 1.08 & 1.66 & 9 & 19.0 & 10.8 \\
\hline 0.10 & 0.68 & 1.27 & 11 & 23.5 & 14.9 \\
\hline
\end{tabular}

Source: Authors' calculations. See text description.

a. The model assumes a general proportional tax on both capital, $\tau_{K}$, and labor, $\tau_{L}$, income of 0.3 .

b. See equation 3 .

to be 1 percent a year; the interest rate is determined endogenously. ${ }^{39}$ The model outlined before was simulated in the case of a general proportional income tax of 30 percent for five values of $\beta(1.10,0.50$, $0.25,0.20$, and 0.10$).{ }^{40}$ Results are presented for the capital-income ratio in the absence and presence of the wealth-nonnegativity constraint, the number of periods for which the consumption is constrained, the percentage of the population constrained, and the percentage of income

39. Results were robust to minor variations in the rate of time preference. We felt that $\rho=0.015$ was a reasonable choice, and the selection of a low discount rate furnishes a lower-bound estimate of the effects of liquidity constraints on consumption and welfare, since a higher rate would only have increased desired consumption relative to current resources.

40. There is some evidence in the literature on the value of $\beta$. In their study of household portfolio allocation, Irwin Friend and Marshall Blume estimate $\beta$ to be less than 0.5. Henry Farber's estimation of preferences of United Mine Workers from collective bargaining agreements yields results consistent with a $\beta$ of about 0.3 . Lars Peter Hansen and Kenneth Singleton find implied estimates of $\beta$ of at least 0.5. Lawrence Summers reports estimates of intertemporal elasticities of about unity using quarterly postwar data. Robert Hall concludes from a set of results that the value for the intertemporal elasticity is roughly zero. We chose a set of values of $\beta$ to span these various estimates. See Irwin Friend and Marshall E. Blume, "The Demand for Risky Assets," American Economic Review, vol. 65 (December 1975), pp. 900-22; Henry S. Farber, "Individual Preferences and Union Wage Determination: The Case of the United Mine Workers," Journal of Political Economy, vol. 86 (October 1978), pp. 923-42; Lars Peter Hansen and Kenneth J. Singleton, "Stochastic Consumption, Risk Aversion, and the Temporal Behavior of Asset Returns," Journal of Political Economy, vol. 91 (April 1983), pp. 249-65; Lawrence H. Summers, "Tax Policy, the Rate of Return, and Savings," Working Paper 995 (National Bureau of Economic Research, September 1982); Robert E. Hall, “Real Interest and Consumption," Working Paper 1694 (National Bureau of Economic Research, August 1985). 
earned by individuals whose consumption is limited by current resources.

As expected, as the intertemporal elasticity of substitution in consumption declines, reflected in lower values of $\beta$, the capital-income ratio rises in the constrained case relative to the unconstrained case. This effect of forced saving through liquidity constraints is also evident in the corresponding increase in the number of periods constrained, the percentage of the population constrained, and the fraction of income earned by constrained consumers. ${ }^{41}$ Note, for example, that in the case wherein $\beta=0.25$, the constrained capital stock is 35 percent larger than the unconstrained capital stock, with borrowing constraints binding on 19 percent of the population receiving 11 percent of disposable income. These results suggest that tax policies that exacerbate the severity or duration of liquidity constraints are likely to lead to substantial welfare costs, especially when the intertemporal elasticity of substitution in consumption is small.

The simulations in table 3 aggregate individual consumption and savings decisions. To check the robustness of our findings of the importance of liquidity constraints in the aggregate, we also consider the effects of changes in family size over the life cycle. This is a consideration that may be important, since individuals may desire more consumption in middle age to finance expenses of rearing and educating children. This could reduce both desired consumption in youth and the impact of any nonnegativity constraint on wealth. The individual utility function in equation 1 is modified to

$$
\int_{0}^{T} n(t) U(c) e^{-\rho t} d t
$$

where $c_{t}$ represents consumption per capita in the household at time $t$ and $n_{t}$ represents the number of adult equivalents in the family at time $t$, where children receive less than the weight of adults in calculating family size.

In our simulations, we consider both the individual case described above and a family case. In the family case we use a study by Walter Dolde for values to assign to the weights for family members of different

41. Our predictions for the fraction of aggregate disposable income earned by constrained individuals are lower than Hayashi's point estimate of 17.1 percent, but, as noted before, our description of borrowing restrictions is most likely an underestimate of their severity in the real world. See Hayashi, "The Permanent Income Hypothesis." 
ages and for a time path of household income. ${ }^{42}$ The results in table 3 are robust to this modification. In particular, liquidity constraints are often more binding and last longer. Individuals do not want to borrow as much in youth, but do want to borrow more and for a longer period in early years of family life, since peak family size (in adult equivalents) is achieved before peak family earnings. In the interest of space, we do not report these modifications here, but do include the results for the family in the important tax policy simulations below.

In summary, the simulations show that a nonnegativity constraint for personal wealth has a substantial effect on the long-run supply of capital. The potential welfare costs associated with the effects of liquidity constraints on consumption do not, of course, imply that society should make large transfers to young, constrained workers. ${ }^{43}$ Constraints with respect to incentive effects and social convention abound. The marginal contribution of taxation to those welfare costs is, however, a legitimate concern of public policy within the context of optimal taxation.

\section{Liquidity Constraints and Tax Policy Evaluation}

Life-cycle simulation models have been used extensively in the area of tax reform-in particular, to measure the welfare effects of switching from a general income tax on both capital and labor income to a tax on labor income alone and from a progressive income tax to a proportional income tax. ${ }^{44}$ According to the findings of recent studies, the first-order

42. Dolde, "Capital Markets." See also Brainard, "Private and Social Risk." In an econometric study, Thomas MaCurdy finds little evidence that children affect life-cycle consumption. See Thomas E. MaCurdy, "A Simple Scheme for Estimating an Intertemporal Model of Labor Supply and Consumption in the Presence of Taxes and Uncertainty," International Economic Review, vol. 24 (June 1983), pp. 265-89.

43. Policymakers have, however, considered such reforms in the context of negative income tax programs or demogrants.

44. For discussions of capital and labor income taxation, see Summers, "Capital Taxation"; Auerbach, Kotlikoff, and Skinner, "The Efficiency Gains"; Owen J. Evans, "Tax Policy, the Interest Elasticity of Saving, and Capital Accumulation: Numerical Analysis of Theoretical Models," American Economic Review, vol. 73 (June 1983), pp. 398-410; Laurence S. Seidman, "Conversion to a Consumption Tax: The Transition in a Life-Cycle Growth Model," Journal of Political Economy, vol. 92 (April 1984), pp. 247-67. For a discussion of progressive and proportional taxation, see Auerbach and Kotlikoff, "National Savings"; Auerbach, Kotlikoff, and Skinner, "The Efficiency Gains." 
welfare effects of either shift can be quite large.$^{45}$

Many recent studies have focused on intertemporal distortion arising from the taxation of capital income. The issues involved in switching from general income taxation - a tax on both capital and labor incometoward taxation of labor income alone can be summarized in a simple two-period model of consumption and labor income. When labor income is exogenous, a general income tax is equivalent to a combination of a lump-sum tax and a tax on interest income. Since the tax reduces the net rate of interest, the system discourages saving and discriminates in favor of present consumption at the expense of future consumption.

Because substitution effects diminish for consumers for whom liquidity constraints are binding or expected to bind, the potential efficiency gains from policy reform are reduced according to the importance of liquidity-constrained consumers in the population. Any increase in labor income taxes to compensate for lost capital income taxes crowds out first-period consumption dollar for dollar for such individuals in a twoperiod world with a binding liquidity constraint in the first period.

In a comparison of capital and labor taxation in the context of a twoperiod model, Martin Feldstein finds significant efficiency gains from moving from a proportional general income tax to a proportional tax on labor income. ${ }^{46}$ The partial equilibrium character of Feldstein's analysis and the single period of labor supply are, however, important qualifications of his results. ${ }^{47}$

Lawrence Summers shows that the efficiency costs of capital income taxation analyzed in a realistic life-cycle model are likely to be much larger than those suggested in two-period models. ${ }^{48}$ The channel for this effect is intuitive. A cut in the capital income tax rate raises the net return to saving, and the substitution effect discourages consumption; for individuals in debt, the income effect further depresses consumption. The resulting decline in consumption can lead to a substantial increase in lifetime saving. Indeed, for the case of an additively separable lifetime

45. See, for example, Summers, "Capital Taxation.",

46. Feldstein, "The Welfare Cost."

47. For a criticism of Feldstein's approximations of loss measures, see Jerry R. Green and Eytan Sheshinski, "Approximating the Efficiency Gain of Tax Reforms," Journal of Public Economics, vol. 11 (April 1979), pp. 179-95.

48. Summers, "Capital Taxation." See also the qualifications of Summers's results in Evans, "Tax Policy," and Seidman, "Conversion to a Consumption Tax." 
utility function with (approximately) logarithmic utility over consumption and inelastically supplied labor, Summers finds an efficiency gain of almost 12 percent of lifetime income from switching from a general income tax to a consumption tax.

The assumption of inelastically supplied labor is not realistic. Also, the marginal welfare cost of factor taxation is the important index of distortion for our purposes. Assuming elastically supplied labor and capital, in a perfect foresight model of general equilibrium, Judd shows that the marginal welfare cost of taxing both labor and capital income taxation is even greater than the welfare cost found by Summers, ranging from twenty-five cents to a dollar per marginal dollar of revenue for central estimates of the critical structural parameters. ${ }^{49}$ This is the critical cost of introducing progressivity into the tax structure, since progressivity is largely an increase in taxation with the extra revenue financing a lump-sum transfer. In order for the result to be welfareimproving, the benefits of the progressivity must exceed the substantial marginal efficiency costs of factor taxation that arise in our model.

Arguments against progressive income taxation focus on distortions in intertemporal consumption decisions and in labor-supply decisions. Using a dynamic life-cycle simulation model with a labor-leisure choice in addition to intertemporal consumption decisions, Alan Auerbach, Laurence Kotlikoff, and Jonathan Skinner find substantial efficiency costs to using a progressive income tax rather than a proportional income tax in financing a given level of government spending. ${ }^{50}$

When liquidity constraints are introduced, important new elements enter the analysis. Consider for example a simple linear (but nonproportional) tax with intercept $-\omega$ and marginal tax rate $t$; the system is progressive or regressive according to whether $\omega$ is greater or less than zero. With perfect capital markets, an increase in the lump-sum transfer to an individual financed by higher tax rates on labor and capital income will distort both working and saving decisions, the magnitudes depending on underlying parameter values. Declines in capital accumulation from reduced saving rates and work effort lower both consumption and lifetime utility of representative consumers in the new steady state. When net

49. Kenneth L. Judd, "The Welfare Cost of Factor Taxation in a Perfect Foresight Model," Journal of Political Economy, forthcoming.

50. Auerbach, Kotlikoff, and Skinner, "The Efficiency Gains." 
asset positions are required to be nonnegative, higher exemption levels (increases in income from increased lump sum transfers) raise consumption dollar for dollar for individuals for whom the constraint binds. The distortions noted above must be contrasted with this utility gain.

With labor supply assumed elastic, the examination of the effects of borrowing restrictions is more complicated, but it is important to simulate such a case for two reasons. First, consideration of the efficiency effects of progressive taxation or of shifts in the relative reliance on capital and labor income taxation requires treatment of behavioral responses of both labor and capital. Second, consumers can ease liquidity constraints on consumption by increasing work during constrained periods, at a cost in individual welfare.

All these considerations provide direction in applying the life-cycle model to realistic parameters in analyzing the effects of tax reform on national saving and resource allocation. The effect of tax reform on the welfare of liquidity-constrained consumers will be important for assessing the aggregate welfare effects of policy changes. Any switch away from capital income taxation toward increased taxation of wage income will entail, ceteris paribus, an efficiency loss from a decline in the consumption of constrained consumers, a loss that must be weighed against the efficiency gain from lessening tax-induced distortions in intertemporal consumption decisions. Similarly, to the extent that earnings rise with age over most of the working life, progressive taxation shifts the individual lifetime of taxation away from constrained periods, permitting gains in lifetime consumption and welfare. Earlier studies focus only on the efficiency costs of distortions in labor supply under progressive taxation. ${ }^{51}$

WELFARE EFFECTS OF CAPITAL AND LABOR INCOME TAXATION

As noted by Summers, capital taxation in a life-cycle growth model can lead to substantial reductions in individual welfare when individuals supply labor inelastically throughout their working lives. ${ }^{52}$ Since reductions in the level of capital taxation will in general be financed by higher

51. These distortions can, of course, be large. See, for example, the estimates by Jerry A. Hausman in "Labor Supply," in Henry J. Aaron and Joseph A. Pechman, eds., How Taxes Affect Economic Behavior (Brookings, 1981), pp. 27-72.

52. Summers, "Capital Accumulation." 


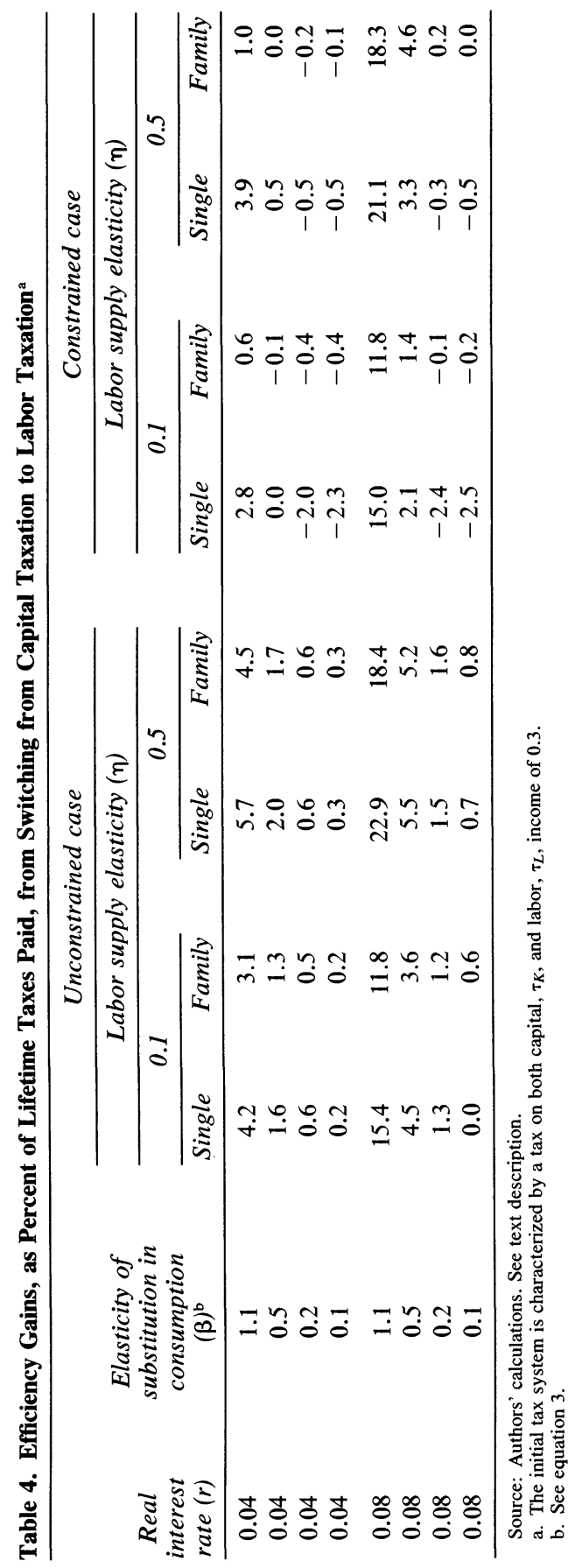


taxes on labor income, to the extent that labor is elastically supplied, the efficiency effects of policy reform are no longer obvious. However, Judd shows that, except in the case of an immediate and temporary capital income tax, a marginal substitution of labor taxation for capital income taxation would be welfare-improving. ${ }^{53}$ The consensus is that intertemporal distortions induced by capital income taxation dominate the contemporaneous distortions due to labor income taxation when capital markets are assumed perfect. Our concern is with the complications that borrowing restrictions introduce.

Our first experiment would eliminate the capital income tax and finance the reform by higher taxes on labor income. We take as our base case a proportional tax on capital and labor income such that $\tau_{K}=\tau_{L}=$ $0.3 .{ }^{54} \mathrm{As} \tau_{K}$ is set equal to zero, we solve for the labor tax rate, $\tau_{L}$, that raises the same revenue as the proportional general income tax. We assume elastic labor supply, making the individual's lifetime utility function described in equation 1 additively separable in consumption and leisure (see the detailed discussion in appendix A). The exercise is conducted under an open-economy assumption, where the interest rate remains at the same level as that prevailing prior to the policy experiment.

To allow for a reasonable range of the underlying parameter values, we perform the experiment for two values of the interest rate, 0.04 and 0.08 . While an 8 percent interest rate is unrealistically high as a representation of any available riskless return, we include it here, since risky assets have expected returns in that range. Since it is not known how to account properly for the riskiness of real-world investments in our deterministic model, we choose to examine these two values, bracketing, we hope, the true best approximation. We also examine two values of the compensated wage elasticity of labor supply, 0.1 and 0.5 (see the discussion in appendix A), and four values of $\beta, 1.1,0.5,0.2$, and 0.1 . Results for changes in individual welfare in unconstrained and constrained cases are reported in table 4 .

53. Judd, "The Welfare Cost."

54. Summers and Feldstein describe the U.S. tax system as being characterized by $\tau_{K}=0.5$ and $\tau_{L}=0.2$. That description is probably unrealistic in the current environment of declining capital taxation. In any event, starting with a higher tax on interest income would accentuate our findings in the constrained regime. Summers, "Capital Taxation"; Martin Feldstein and Lawrence Summers, "Inflation and the Taxation of Capital Income in the Corporate Sector," National Tax Journal, vol. 32 (December 1979), pp. 445-70. 
For each combination of labor supply elasticity and capital market specification, we report the efficiency gain for both the "single" case and the "family" case. The single case should not be interpreted literally as a single individual, but as one in which the family size does not vary much over time or has relatively little impact on consumption demand. These two cases cover a wide range of beliefs concerning the impact of family experience on intertemporal demand (see appendix A) and indicate the sensitivity of our analysis to such factors. In all cases, efficiency gains are expressed as a percentage of lifetime taxes paid. ${ }^{55}$

As expected, in the unconstrained case, substantial efficiency gains are achieved by moving from capital to labor income taxation. Gains are largest for high values of the intertemporal elasticity of substitution in consumption, where the sensitivity of saving to changes in the net return is substantial. These gains are mitigated substantially in the constrained case. As the intertemporal elasticity of substitution in consumption assumes smaller values in the constrained case, the effect of the borrowing restrictions becomes more significant, and the switch from capital income to labor income taxation leads to much smaller gains than in the unconstrained case and even, in some cases, to welfare costs. For example, from table 4 , when $r=0.04, \beta=0.2$, and $\eta=0.1$, a 0.6 percent gain from eliminating capital taxation when capital markets are perfect becomes a 2.0 percent loss with liquidity constraints.

Nor does the pattern of gains and losses in the family case differ qualitatively from that in the single case. The family-size elements moderate the gains and losses, but even these quantitative differences are not large. In both cases, the addition of liquidity constraints substantially affects and often reverses the efficiency gains that would otherwise arise.

RECONSIDERING THE COSTS OF PROGRESSIVE INCOME

TAXATION

Debates over the effects of progressive income taxation on work effort and saving have figured prominently in the policy agenda in recent years. In particular, estimates of significant effects of the tax system on

55. At first blush, the pattern of results in table 4 by labor supply elasticity may appear counterintuitive. One might suspect that the efficiency gain from switching from capital taxation to labor taxation should be less the more elastic is labor supply with 
labor supply have raised the specter of large deadweight losses on the margin from progressive taxation. ${ }^{56}$ Proposals to modify the general income tax toward a proportional tax system cite the potential efficiency gains from mitigating these distortions. ${ }^{57}$

Our findings for the case of capital taxation suggest that, in the presence of significant restrictions on borrowing, delays in tax collection over an individual's lifetime are important in assessing the efficiency effects of tax reform. For many plausible underlying parameter values, capital income taxation is efficiency-improving because it effectively delays the collection of tax payments over an individual's life cycle. A switch from progressive to proportional income taxation would speed up tax collection, raising tax rates on low-income consumers and reducing their consumption substantially when liquidity constraints are important.

Proponents of proportional taxation have suggested that increased exemptions could maintain the equity or political acceptability of the tax code. ${ }^{58}$ When borrowing restrictions are important, exemptions can serve efficiency functions as well. Below, we examine the effects of going from a strictly proportional tax on all income to a "progressive" proportional tax with an intercept-exemption-and a single marginal tax rate that raises the same revenue. Including a sequence of tax brackets applying to different income levels would raise the welfare costs of progressive taxation. Our aim here is to call attention to the role of exemptions, to introduce the possibility that progressive taxation per se need not carry a deadweight loss. The implicit trade-off is between the saving and labor supply distortions from higher marginal taxes on capital and labor income under progressive taxation on the one hand and the efficiency gain from relaxing borrowing constraints on low-income individuals on the other. For low values of the intertemporal elasticity of substitution in consumption, the latter effect is likely to dominate; for high values, the former.

respect to changes in the net wage. Here the intertemporal distortion from interest taxation is more important than the static consumption-leisure distortion. That is, reducing the intertemporal distortion dominates the fact that the static distortion becomes greater.

56. See, for example, Hausman, "Labor Supply."

57. See, for example, Robert E. Hall and Alvin Rabushka, The Flat Tax (Hoover Institution, 1985).

58. Ibid. 


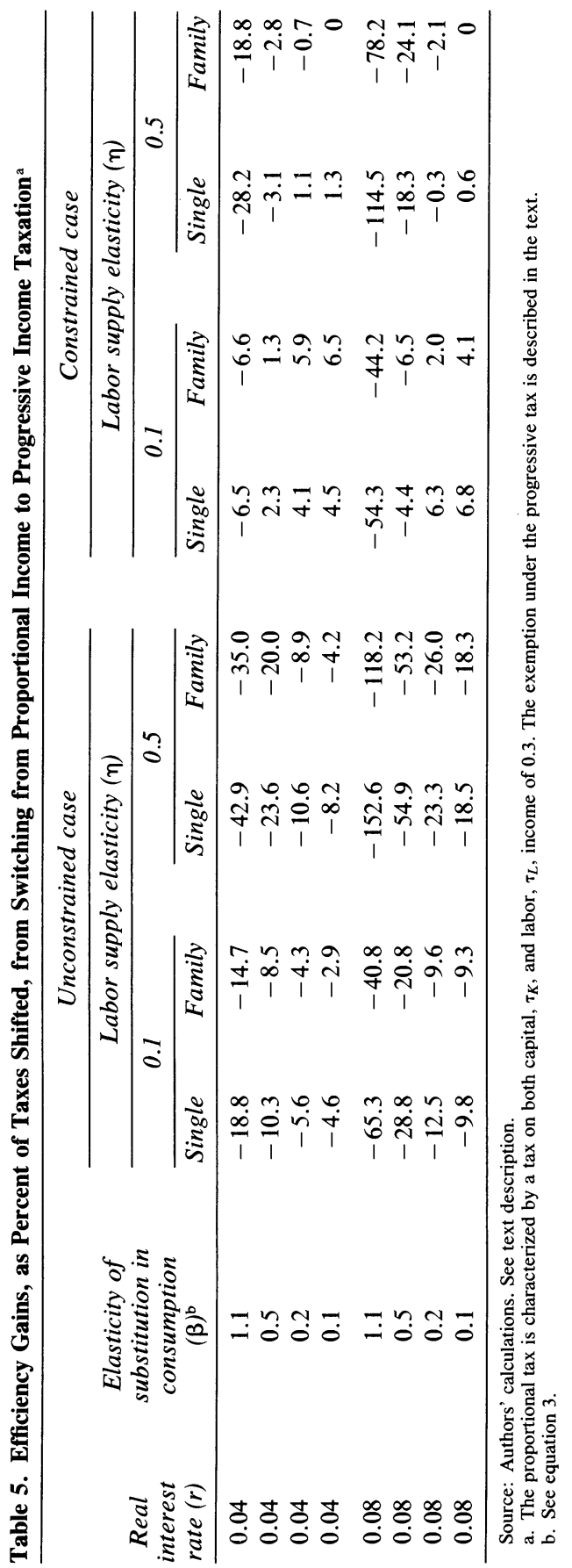


Using an exemption, we calculate the constant marginal tax rate required to raise the same revenue as a proportional income tax at a rate of 30 percent. The exemption is calibrated to be two-thirds of first-year earnings (about 15 percent of highest earnings). We simulate interest rate values of 0.04 and 0.08 , labor supply elasticity values of 0.1 and 0.5 , and $\beta$ values of $1.1,0.5,0.2$, and 0.1 . Dollar-equivalent efficiency gains and losses are calculated relative to taxes shifted. That is, for each individual, the switch to progressive taxation grants an income increment equal to the present value of the new marginal tax rate times the exemption level, at a cost of higher taxes paid on the margin at the new marginal tax rate. Our percentage efficiency change is calculated as the quotient of the dollar-equivalent efficiency gain or loss and this effective income change from the imposition of the exemption.

Results are reported in table 5.59 The change to progressive taxation leads to substantial efficiency losses under perfect capital markets, the losses increasing with the magnitude of the elasticity of labor supply, as expected. Even with the significant increase in marginal tax rates (and hence distortions, which initially rise with the square of the tax rate) required to raise the same amount of revenue over the individual's

59. While an analysis of the transition from the steady state of the economy under proportional taxation to one with the progressive tax would be desirable, there are several problems. Most worrisome is the fact that overlapping generations models such as these can have a continuum of such transition paths. See Timothy J. Kehoe and David K. Levine, "Comparative Statics and Perfect Foresight in Infinite Horizon Economies," Econometrica, vol. 53 (March 1985), pp. 433-53, for a discussion of these issues.

The presence of a continuum of transition paths means that the results of comparativedynamic experiments are indeterminate. It is also true that there may be no transition path to a new steady state, implying that the imposition of a nonlinear tax would precipitate cyclical or chaotic behavior. These perverse possibilities are usually made more likely by the absence of a market, as is the case with our liquidity constraints. Hence, the technical problems are beyond the scope of this study.

Some attempts have been made at transition analysis, but their results must be regarded as tentative. Auerbach, Kotlikoff, and Skinner employ an algorithm for which there is at best only a proof of local validity; that is, if the initial guess is "close enough", to the answer, then the algorithm will converge to the answer. They do not rule out the possibility that the algorithm may stop at other points. Furthermore, they do not show that there is only one such transition path to find in their model. These points indicate that more analysis of their algorithm and model is necessary before their interesting and important results are fully validated. Finally, while we would like to have used their algorithm for some indication of transition effects, it is not available, and we have not endeavored to redevelop it independently here. Auerbach, Kotlikoff, and Skinner, "The Efficiency Gains." 


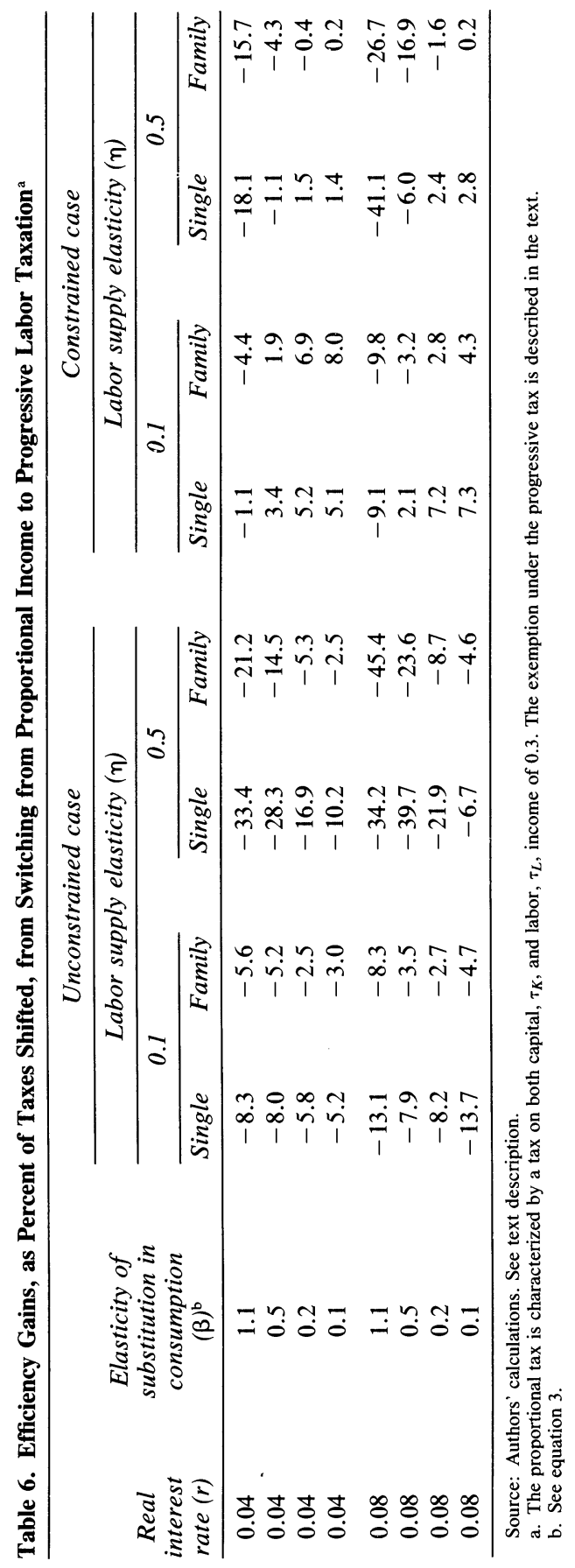


lifetime, the inclusion of borrowing restrictions in the analysis substantially mitigates losses in all cases. For example, in the single individual case with $r=0.04, \beta=0.5$, and $\eta=0.1$, the loss of 10.3 percent (relative to taxes shifted) under perfect capital markets becomes a 2.3 percent gain in the liquidity-constrained regime. Even more striking is the finding that for a relatively inelastic labor supply and a low intertemporal elasticity of substitution in consumption, efficiency gains accompany progressive taxation. That is, the exemption here serves an efficiency role in the presence of liquidity constraints. ${ }^{60}$ Again, the results in the family case are similar.

Our findings in the experiments with capital and labor taxation and with progressive and proportional taxation suggest potential gains from a progressive tax on labor income only, with no taxation of interest income. Such a reform would mitigate the impact of taxation on the consumption of constrained individuals without introducing the intertemporal distortions inherent in capital taxation. To examine this hypothesis, we simulate a shift away from a proportional general income tax of 30 percent. The new system sets $\tau_{K}=0$, imposing all taxation on labor income and granting the same exemption as before. The constant marginal tax rate on labor income above the exemption is raised to ensure revenue neutrality. Results for the same parameters as before, presented in table 6 , show that exemptions are generally less costly and more often beneficial when imposed on top of a labor income tax than when imposed on both capital and labor taxes. This finding validates our intuition that the exemption attacks the liquidity-constraint problem and works better when it does not aggravate intertemporal distortions, even though it must aggravate labor supply distortions even more.

Comparing the findings of tables 4,5 , and 6 reveals the significance of liquidity constraints for considering alternative tax changes. The efficiency changes in table 4 can be expressed in units comparable to those in tables 5 and 6 , given information on taxes shifted relative to lifetime taxes paid. As a benchmark, the present value of the exemption is about one-fifth of lifetime taxes when intertemporal substitution is high, about one-third of lifetime taxes when intertemporal substitution is low. The

60. This is in contrast to simulations ignoring the potential effects of liquidity constraints. For example, Hausman finds that the welfare cost of progressive income taxation described in this way increases with the amount of the exemption. Hausman, "Labor Supply," p. 64, table 1. 
efficiency changes of all three policies considered are thus of comparable magnitude.

\section{POLICY IMPLICATIONS AND EXTENSIONS}

This framework for reconsidering the efficiency effects of tax reform suggests the potential importance of other preexisting distortions in influencing the outcome of changes in fiscal policy. In particular, many government programs, most notably social insurance programs, affect agents' lifetime budget constraints to the extent that private insurance against uncertainty over length of life, job loss, catastrophic illness, and so on, is incomplete. When social insurance is examined in the framework of precautionary saving, its provision will in general affect lifetime consumption and not just consumption during the periods in which payments are received. ${ }^{61}$

Since Martin Feldstein first examined the impact of social security over the life cycle, other studies have followed suit. ${ }^{62}$ Empirical work has tested the impact on preretirement consumption of the wealth transfers accompanying the introduction of the existing pay-as-you-go social security system. Extending this discussion, recent studies show that, in the context of lifetime uncertainty, even an actuarially fair, fully funded social security system could generate partial equilibrium increases in lifetime welfare. ${ }^{63}$ Hence previous partial equilibrium estimates of the impact of social security on consumption based on intergenerational wealth transfers at the introduction of the system may be too small.

The extent to which consumers can spread the benefits from social security annuities over their lifetimes depends on the degree to which capital markets permit consumption smoothing when current resources are insufficient. More important, the proportional payroll tax used to

61. Daniel S. Hamermesh, "Social Insurance and Consumption: An Empirical Inquiry," American Economic Review, vol. 72 (March 1982), pp. 101-113; Hubbard, " 'Precautionary' Saving."

62. Martin Feldstein, "Social Security, Induced Retirement and Aggregate Capital Accumulation," Journal of Political Economy, vol. 82 (September-October 1974), pp. 905-26.

63. Andrew B. Abel, "Precautionary Saving and Accidental Bequests," American Economic Review, vol. 75 (September 1985), pp. 777-91; Hubbard, “' 'Precautionary' Saving"; Hubbard and Judd, "Social Security." 
finance social security depresses consumption dollar for dollar when liquidity constraints are binding. Including realistic limitations on borrowing in the life-cycle model introduces the possibility that increasing payroll-tax-financed social security benefits may decrease utility to individuals from lifetime consumption while increasing potential lifetime resources. In a related effort, we demonstrate that precautionary saving within the life-cycle model may be even more important than the effects of borrowing restrictions noted here in explaining national saving and also show that the steady-state efficiency cost of social security under payroll-tax finance can be substantial. ${ }^{64}$ In keeping with the results we have presented here, some consideration of alternative, more progressive means of financing the system, such as the use of earned income credits, would be useful.

It might also be useful to examine the importance of earnings uncertainty, a potential motivation for lenders' unwillingness to finance noncollateralized loans. In preliminary calculations, we do not find that the introduction of even substantial variation in an individual's earnings in the presence of liquidity constraints affects our results to any great degree. The principal effect of liquidity constraints on consumption comes from the resulting inability to achieve the desired consumption profile over the life cycle.

\section{Tax Cuts, Deficits, and Consumption}

The issue of whether government budget deficits affect aggregate demand lies at the center of another important debate in macroeconomics and public finance. The recent resurgence of arguments for the "Ricardian equivalence" proposition that debt-financed tax cuts should have no real effects on consumer spending calls into question whether the life-cycle formulation is an adequate representation of decisionmaking about consumption. ${ }^{65}$ Indeed, the arguments claim that the operative planning period may be the infinite horizon of a dynastic family.

The planning horizon is a major focus of the debate between alternative schools of thought on the potential for economic stimulus of temporary

64. Hubbard and Judd, "Social Security."

65. Barro, "Are Government Bonds Net Wealth?" 
tax reductions. ${ }^{66}$ Olivier Blanchard emphasizes the nonneutrality of changes in the timing of taxes in a model of individuals with finite horizons. ${ }^{67}$ Below we also use a finite-horizon model to highlight the relative importance of liquidity constraints and finite life for the consideration of Ricardian-neutrality propositions. Much of the policy debate over Ricardian equivalence hinges on the relevance of finite-horizon models. We show that policy effectiveness arguments are more affected by liquidity constraints than by considerations of finite horizons.

That individual consumers should respond less to temporary tax changes than to permanent tax changes is noted in Milton Friedman's initial treatment of the permanent-income hypothesis ${ }^{68}$ Under the basic version of the life-cycle model with only a lifetime budget constraint, a temporary tax cut followed by an anticipated offsetting tax increase should have no effect on consumer spending. An obvious qualification is that the aggregate marginal propensity to consume out of a temporary tax cut will be positive to the extent that liquidity constraints affect a substantial number of consumers. ${ }^{69}$ Empirical studies note at least some sensitivity of consumer spending to temporary tax changes. ${ }^{70}$ In partic-

66. See, for example, Barro, "Are Government Bonds Net Wealth?"; Martin Feldstein, "Government Deficits and Aggregate Demand," Journal of Monetary Economics, vol. 9 (January 1982), pp. 1-20.

67. Olivier J. Blanchard, “Debt, Deficits, and Finite Horizons," Journal of Political Economy, vol. 93 (April 1985), pp. 223-47.

68. Milton Friedman, A Theory of the Consumption Function (Princeton University Press, 1957). See also the formal statement in Robert Eisner, "Fiscal and Monetary Policy Reconsidered," American Economic Review, vol. 59 (December 1969), pp. 897905.

69. Note that this effect is more important still the more the number of constrained consumers increases in economic downturns.

70. Arthur Okun used the consumption equations of four macroeconometric models to analyze the effects of the 1968 surtax and found that the "full effect" view fit the data better (in the sense of a smaller root mean square error in simulations) than a "zero effect" interpretation. Blinder and Robert Solow found that an "intermediate view" did better still. William Springer used a consumption function more closely based on the permanent-income hypothesis, concluding that the zero effect view more closely described the outcome. Thomas Juster reached similar conclusions to those of Okun for the 1975 rebate, while Modigliani and Charles Steindel found very little short-term effect. Arthur Okun, "The Personal Tax Surcharge and Consumer Demand, 1968-70," BPEA, 1:1971, pp. 167-204; Alan S. Blinder and Robert M. Solow, "Analytical Foundations of Fiscal Policy," in Alan S. Blinder and others, eds., The Economics of Public Finance (Brookings, 1974), pp. 3-115; William L. Springer, "Did the 1968 Surcharge Really Work?" American Economic Review, vol. 65 (September 1975), pp. 
ular, Blinder finds, in a 1981 paper, that consumers treat a temporary tax change as half ordinary income change and half windfall. ${ }^{71}$ In a 1985 paper coauthored with Angus Deaton, however, Blinder finds that the short-run effects of temporary tax changes correspond more closely to those predicted by the permanent-income hypothesis. ${ }^{72}$ Within the framework of the analytical model described earlier, we can examine the extent to which borrowing restrictions can generate effects of temporary tax changes that are consistent with some of these empirical studies.

At least three obstacles make econometric analysis of temporary tax changes difficult. First, as noted by Arthur Okun and Blinder, consumer responses to tax increases or decreases depend not so much on the announcement of whether they are temporary or permanent, but on whether consumers believe they are temporary or permanent. ${ }^{73}$ Second, in a progressive tax system, tax rate cuts or rebates based on previous tax payments involve relatively small changes for those with very low incomes and little or no tax obligation. Deviations from predictions of the permanent-income hypothesis may therefore be difficult to detect even when a significant fraction of the population is liquidity constrained in the sense defined here. Finally, the existence of a set of constrained consumers does not imply that the aggregate marginal propensity to consume (MPC) out of an explicitly temporary tax cut is equal to the proportion of the population that is liquidity constrained ${ }^{74}$ Clearly, for very small changes, constrained individuals will spend the entire increase in resources; for large enough changes, the constraint may no longer bind. In general, even liquidity-constrained individuals will smooth their

644-59; F. Thomas Juster, "A Note on Prospective 1977 Tax Cuts and Consumer Spending" (University of Michigan, January 1977); Franco Modigliani and Charles Steindel, "Is a Tax Rebate an Effective Tool for Stabilization Policy?" BPEA, 1:1977, pp. 175-203.

71. Alan S. Blinder, "Temporary Income Taxes and Consumer Spending," Journal of Political Economy, vol. 89 (February 1981), pp. 26-53. See also R. Glenn Hubbard, "Temporary Tax Reductions as Responses to Oil Shocks,"' in Alvin L. Alm and Robert J. Weiner, eds., Oil Shock: Policy Response and Implementation (Ballinger Press, 1984), pp. 121-28.

72. Blinder and Deaton, "The Time Series Consumption Function Revisited."

73. Okun, "The Personal Tax Surcharge", Blinder, "Temporary Income Taxes.",

74. This approach is taken in Hall and Mishkin, "The Sensitivity of Consumption"; and in Hayashi, "The Permanent Income Hypothesis." 
consumption response to the increase in resources so as to avoid swings in consumption.

\section{LIQUIDITY CONSTRAINTS AND RICARDIAN NEUTRALITY}

To capture the importance of liquidity constraints for analyzing whether temporary tax changes affect aggregate demand, we make use of a tractable analytical model. We consider a simple economy in which the number of births is constant each year and each person has a probability $p$ of dying each year. This form of uncertainty about life expectancy is highly stylized and serves only to create a finite-horizon problem, not to calculate age-related marginal propensities to consume per se. To focus on life-cycle effects, we capture the essence of a rising lifetime earnings profile by assuming that each person begins work earning a wage of $w_{1}$ and has a probability $q$ each year of experiencing an increase in his wage to $w_{2}$. In the steady state, the share of the labor force in the high-productivity state is $\theta_{2}=q /(p+q)$; the share in the low-productivity state, $\Theta_{1}=p /(p+q)$. Also, the total wage income going to low-productivity workers equals $\Theta_{1} w_{1}$ per living person, and wage income to high-productivity workers is $\theta_{2} w_{2}$ per capita.

All agents are assumed to have logarithmic utility functions defined over consumption; this is just an example from the more general specifications used in the simulation exercises before. Therefore, if $T$ is the time of death, utility is given by

$$
U=E_{T}\left\{\int_{0}^{T} e^{-\rho t} \ln c d t\right\},
$$

where $\rho$ is the rate of time preference. This assumption simplifies exposition because logarithmic utility implies that an individual's consumption in each period is proportional to his human capital-that is, the expected present value of future wages plus financial assets-in perfect capital markets. More specifically, if $h$ is the expected present value of all future wage income and $a$ is financial wealth, then the individual consumption function, $c$ (derived in appendix $\mathrm{B}$ ), is

$$
c=(\rho+p)(h+a) \text {. }
$$

To determine aggregate consumption, it is necessary to compute the human capital of both the low- and high-productivity workers. Since the 
concern is with aggregate indexes, $H_{1}$ and $H_{2}$ are defined as the expected present value per capita of all future wages paid to those currently in low- and high-productivity states, respectively. If $A$ is the financial wealth per capita of those currently alive, the sum $A+H_{1}+H_{2}$ is the total wealth of the current population.

Where capital markets are perfect and there are no restrictions on borrowing, ${ }^{75}$ aggregate consumption, $C$, is given by

$$
C=(\rho+p)\left(A+H_{1}+H_{2}\right) .
$$

In the steady state of the aggregate economy, $H_{1}, H_{2}$, and $A$ assume the values $H_{1}^{*}, H_{2}^{*}$, and $A^{*}$, respectively, where

$$
\begin{aligned}
& H_{1}^{*}=\left(\frac{p}{p+q}\right)\left(\frac{w_{1}}{p+r}\right)+\left(\frac{q}{p+q}\right)\left(\frac{w_{2}-w_{1}}{p+r}\right)\left(\frac{p}{p+q+r}\right), \\
& H_{2}^{*}=\frac{w_{2} \Theta_{2}}{p+r}, \text { and } \\
& A^{*}=\frac{w_{2}(r-\rho)}{(\rho+p+r)(p+r)}+\left(\frac{w_{1}-w_{2}}{\rho+p+r}\right)\left(\frac{p}{p+q}\right)\left(\frac{q+r-\rho}{q+p+r}\right) .
\end{aligned}
$$

Assume $r>\rho$, so that $A^{*}>0$. The human capital of high-productivity individuals is obtained by means of a simple present-value calculation. The coefficient $H_{1}^{*}$ is a weighted average of the discounted low-productivity earnings and later high-productivity earnings, adjusted for transition probabilities. See the more detailed discussion in appendix B.

If an individual enters the economy with no assets and can borrow against future earnings, he may take on some debt. When he starts working, he has his low-productivity human capital, $h_{1}$, where

$$
h_{1}=\frac{w_{1}}{p+r}+\left(\frac{w_{2}-w_{1}}{p+r}\right)\left(\frac{q}{p+q+r}\right) \text {. }
$$

That is, $h_{1}$ represents the discounted value of receiving $w_{1}$ until death, plus the discounted value of the difference until death between $w_{2}$ and $w_{1}$, times the probability of reaching high productivity, $q /(p+q)$, times

75. That capital markets are perfect implies the ability both to borrow against future earnings and to insure against a delayed transition into high productivity and long life. Here we will assume the existence of annuity markets. For an examination of the implications of their absence and of liquidity constraints for social security financing, see Hubbard and Judd, "Social Security." 
the expected discount factor at the time of that transition conditional on having reached high productivity, $(p+q) /(p+q+r)$. The inclusion of the second term in $h_{1}$ is due to the perfect capital market that allows the individual to borrow against the future high-productivity wage stream. Desired consumption in the initial period is

$$
c_{0}=(\rho+p) h_{1}=\frac{\rho+p}{p+r} w_{1}\left[1+\left(\frac{w_{2}}{w_{1}}-1\right)\left(\frac{q}{p+q+r}\right)\right] .
$$

Note that $c_{0}>w_{1}$ if $w_{2}$ is much greater than $w_{1}$, or if $q$ is large relative to $p+r$. Intuitively, initial consumption exceeds the initial wage if the initial wage is much smaller than subsequent wages or if the transition to higher wages is especially rapid.

If low-wage individuals cannot borrow against future high wages and desired initial consumption exceeds the initial wage, consumption behavior is substantially affected. For the case in which $q$ is high and assets are zero for constrained individuals, we need only examine $H_{2}^{*}$ and $A^{*}$ in the aggregate analysis, since consumption equals the wage for all lowproductivity workers. Therefore, in the steady state of the constrained system,

$$
\begin{gathered}
\boldsymbol{H}_{2}^{*}=\frac{w_{2} \Theta_{2}}{p+r} \text {, and } \\
A^{*}=\frac{w_{2} \Theta_{2}(r-\rho)}{(\rho+p+r)(p+r)} .
\end{gathered}
$$

As expected, the constrained equilibrium yields a greater steady-state asset level, the increase equaling

$$
\left(\frac{w_{2}-w_{1}}{\rho+p+r}\right)\left(\frac{p}{p+q}\right)\left(\frac{q+r-\rho}{q+r+p}\right) .
$$

The difference is large as the productivity difference and the proportion of liquidity-constrained individuals is greater. The ratio of steady-state asset levels in the constrained and unconstrained cases is

$$
\left(\frac{w_{2}-w_{1}}{\rho+p+r}\right)\left(\frac{p}{q}\right)\left(\frac{q+r-\rho}{q+r+\rho}\right)\left(\frac{p+r}{r-\rho}\right) .
$$

As with the earlier simulations, this fraction is not trivial. For example, if $p=0.02, q=0.08, r=0.04, \rho=0.015$, and $w_{1}=0.7 w_{2}$, then the capital stock is 14 percent smaller in the unconstrained case. 
The effects of temporary tax changes on consumption can be analyzed easily in this framework. As the simplest possible case, suppose that taxes, $\tau(t)$, per capita are imposed at time $t$. Viewing such taxes as reductions in the wage shows that the human capital of each current worker at time $t$ is reduced by

$$
T(t)=\int_{t}^{\infty} e^{-r(s-t)} e^{-p(s-t)} \tau(s) d s .
$$

As pointed out by Blanchard, debt-financed tax cuts are not neutral even in the presence of perfect capital markets, since a reduction in current taxation financed by higher taxation of future generations stimulates a positive wealth effect for the current generation, causing its consumption to rise. ${ }^{76}$

This perfect-markets impact is small, however. Suppose, for example, that $\tau(t)$ is decreased by $d \tau$ during the interval $\left[0, t_{1}\right]$, with a compensating tax increase of $e^{r t_{2}}$ during the interval $\left[t_{2}, t_{1}+t_{2}\right]$. In that case, total human capital net of taxes for individuals at $t=0$ increases by $\left(1-e^{-p t_{2}}\right)\left(1-e^{-(r+p) t_{1}}\right)(r+p)^{-1}$. Therefore, the marginal propensity to consume out of a debt-financed tax cut, $m$, is

$$
m=\frac{d C}{d \tau}=(\rho+p)\left(1-e^{-p t_{2}}\right)\left(\frac{1-e^{-(r+p) t_{1}}}{r+p}\right) .
$$

The marginal propensity to consume out of a tax cut involves the three terms on the right-hand side of the equation. The first, $(\rho+p)$, is the MPC out of increments to wealth. The other two terms comprise the increment to wealth. That increment is greater the longer the tax cut lasts and the longer is the delay before the compensating tax increase. The present value of the tax cut during $\left[0, t_{1}\right]$ is $\left(1-e^{-(r+p) t_{1}}\right) /(r+p)$. Only $1-e^{-p t_{1}}$ of that is left after expected future taxes are considered. While $(\rho+p) /(r+p)$ may very well be close to unity, the other terms are substantial only if $p, t_{1}$, or $t_{2}$ is large. For example, if $p=0.02$, $\rho=0.015, r=0.04, t_{1}=5$, and $t_{2}=20$, we are considering a five-year tax cut financed with a twenty-year delay, during which time people die at a rate of 2 percent a year. In this case, the MPC out of a tax cut would be only about 0.05 , even though we postulated an extended tax cut financed with a relatively long delay.

76. Olivier J. Blanchard, “Debt, Deficits, and Finite Horizons," Journal of Political Economy, vol. 93 (April 1985), pp. 223-47. 
Results in a liquidity-constrained regime are quite different. Suppose low-productivity workers consume their wage. Then the impact of a tax cut is just

$$
d C=\Theta_{1} d \tau_{1}+\Theta_{2} d \tau_{2},
$$

where $d \tau_{i}$ is the size of the tax cut for workers of productivity $w_{i}$. The aggregate MPC out of the tax cut,

$$
\bar{m}=\frac{\Theta_{1} d \tau_{1}+\Theta_{2} m d \tau_{2}}{\Theta_{1} d \tau_{1}+\Theta_{2} d \tau_{2}}
$$

will be substantially higher. Suppose $\Theta_{1}=0.20$ and $d \tau_{1}=d \tau_{2}$. The aggregate MPC becomes 0.24 , not 0.05 . The MPC is more than quadrupled by assuming that only 20 percent of the work force is liquidity constrained. With shorter delays, this contrast is even more striking.

This result is straightforward: the aggregate MPC out of a temporary tax change is just a weighted average of the low MPCs of unconstrained households and the high MPCs, equal to unity, of constrained households. Under such a modeling structure, econometric evidence on the effect of temporary tax changes on consumption could be used to infer the importance of liquidity-constrained consumers in the determination of aggregate consumption. These findings are of particular interest for the debate over tests of Ricardian equivalence. While finite horizons per se are not likely to be of much significance for analyses of whether fiscal policy changes are neutral with respect to aggregate demand, capitalmarket imperfections should be quantitatively important in invalidating neutrality propositions.

EFFECTS OF THE DISTRIBUTION OF TAX CUTS ON CONSUMPTION

The formulation of $\bar{m}$ in equation 21 highlights the importance of the distribution of the tax cut. Letting $\Omega=d \tau_{2} / d \tau_{1}$, we can rewrite equation 21 as:

$$
\bar{m}=\frac{\Theta_{1}+\Theta_{2} \Omega m}{\Theta_{1}+\Theta_{2} \Omega} .
$$

When $d \tau_{1}$ and $d \tau_{2}$ are not equal, liquidity constraints become less important. For example, if instead of a uniform tax cut, low-income workers enjoy a smaller absolute tax cut than high-income workers doboth cuts financed separately by later increases in taxes in the same 
class-then $\bar{m}$ is reduced. This case is, of course, a more relevant and realistic one to examine. Many changes in progressive tax systems result in greater relative relief for the high-income group. Changes in tax structure making the system more progressive, such as increases in exemptions compensated by higher marginal tax rates, render smaller the aggregate MPC out of a temporary tax cut. That is, under a progressive system with an exemption $\omega$ and marginal tax rate $t, \Omega=\left(w_{2}-\omega\right) /\left(w_{1}-\omega\right)$. If, for example, $\Omega=2$, the $\bar{m}$ calculated before falls to about 0.16 . Making the tax system less progressive increases the fraction of the population constrained, raising the sensitivity of aggregate consumption to temporary tax changes.

The results of these cases for both infinite-horizon (that is, where $p=0$ ) and finite-horizon models are summarized in table 7 under various assumptions about the proportion of the population that is liquidity constrained. The aggregate MPCs are calculated for a five-year tax cut financed by either a twenty-year delay or a ten-year delay. Three conclusions are readily apparent. First, the significant variation in aggregate MPCs stems primarily from capital market imperfections, not from changes in the planning horizon. Second, shorter delays for compensating tax increases only reinforce the relatively greater MPCs associated with the presence of liquidity constraints. Third, distributional features of tax cuts are important in both finite-horizon and infinitehorizon models when liquidity constraints are considered.

The dependence of the aggregate MPC on the structure of the tax cut points up clearly the potential problems of using estimates of the effects of temporary tax changes on consumption to make inferences about the importance of liquidity-constrained consumers in the economy. In the simple examples noted above, the underlying fraction of the population with constrained consumption was held constant, yet MPCs varied substantially with respect to lump-sum, proportional, and progressive tax reductions. In particular, to the extent that many previous actual policy experiments involved temporary changes in nonlinear tax systems, their effects on consumption would be small even in the presence of a substantial number of liquidity-constrained consumers.

\section{POLICY IMPLICATIONS}

Thus far, we have concentrated on the income effects of tax policy. But taxes are not lump-sum and have substitution effects as well. While 
Table 7. Simulated Aggregate Marginal Propensity to Consume Out of a Temporary Tax Cut ${ }^{\mathrm{a}}$

Percent

\begin{tabular}{|c|c|c|c|}
\hline \multirow[b]{2}{*}{$\begin{array}{l}\text { Fraction of population } \\
\text { liquidity-constrained }\end{array}$} & \multirow{2}{*}{$\begin{array}{l}\text { Perfect } \\
\text { capital } \\
\text { markets }\end{array}$} & \multicolumn{2}{|c|}{ Liquidity constraints } \\
\hline & & $\begin{array}{l}\text { Lump-sum } \\
\text { tax cut }\end{array}$ & $\begin{array}{l}\text { Non-lump-sum } \\
\text { tax cut }\end{array}$ \\
\hline \multicolumn{4}{|l|}{ Infinite-horizon modele } \\
\hline \multicolumn{4}{|l|}{ Twenty-year delay } \\
\hline 0 & 0 & 0 & 0 \\
\hline 10 & 0 & 10 & 5.3 \\
\hline 20 & 0 & 20 & 11.1 \\
\hline 25 & 0 & 25 & 14.3 \\
\hline \multicolumn{4}{|l|}{ Ten-year delay } \\
\hline 0 & 0 & 0 & 0 \\
\hline 10 & 0 & 10 & 5.3 \\
\hline 20 & 0 & 20 & 11.1 \\
\hline 25 & 0 & 25 & 14.3 \\
\hline \multicolumn{4}{|l|}{$\begin{array}{l}\text { Finite-horizon model } \\
\text { Twenty-year delay }\end{array}$} \\
\hline 0 & 5.0 & 5.0 & 5.0 \\
\hline 10 & 5.0 & 14.5 & 10.0 \\
\hline 20 & 5.0 & 24.0 & 15.6 \\
\hline 25 & 5.0 & 28.8 & 18.6 \\
\hline \multicolumn{4}{|l|}{ Ten-year delay } \\
\hline 0 & 2.7 & 2.7 & 2.7 \\
\hline 10 & 2.7 & 12.4 & 7.8 \\
\hline 20 & 2.7 & 22.2 & 13.5 \\
\hline 25 & 2.7 & 27.0 & 16.6 \\
\hline
\end{tabular}

Source: Authors' calculations. See text description.

a. The aggregate marginal propensity to consume is calculated for a five-year tax cut financed by a twenty-year delay or a ten-year delay. The experiment is discussed in the text.

b. Corresponds to $\Theta_{1}$ in the model.

c. $d \tau_{1}=d \tau_{2}$ in the model.

d. The aggregate marginal propensity to consume is governed by equation 22 in the text under the assumption that $\Omega=2$.

e. The optimizing horizon is infinite.

$\mathrm{f}$. The optimizing horizon is finite.

a complete integration is beyond the scope of our efforts here, we can relate our results to other discussions of Ricardian neutrality that do consider the distortionary substitution effects that arise from taxation.

Judd shows that in a perfect-foresight representative-consumer model, a substitution of debt for taxes will often lead to an anti-Keynesian effect; that is, the MPC out of the tax cut is negative. ${ }^{77}$ The explanation is clear.

77. Kenneth L. Judd, "Debt and Distortionary Taxes," Journal of Monetary Economics, forthcoming. 
A tax cut today followed by a future tax increase will increase the welfare cost of taxation, since the future tax increase will depress the future capital stock, whereas the current tax cut cannot increase the current capital stock. This adverse income effect on current consumption accentuates the substitution, or price, effect arising from the lowered cost of future consumption. Hence, both price and income effects act to reduce consumption if taxes are temporarily reduced. Furthermore, the magnitude of this effect is comparable to the income effect of bonds in standard Keynesian analysis of debt versus taxes and hence is not trivial by the standards of this debate. Therefore, incorporating distortionary taxation into the debt-versus-taxes debate introduces a significant and opposing element.

These observations make clear three forces that should be considered in thinking about the reaction of aggregate consumption to tax changes. First, there will be intergenerational wealth redistribution, the focus of finite-life analyses. Second, and quantitatively more important, responses will be affected by liquidity constraints. Third, income and price effects due to the distortionary nature of taxation will also affect consumption. Synthesizing these three considerations suggests the following. For those who actively participate in the capital market, the wealth-redistribution and distortionary-tax effects are both important but act to cancel each other, since they pull consumption in opposite directions. Liquidity-constrained consumers are not going to be affected by changing savings incentives and will react strongly to net-of-tax income changes. However, most reforms do not give much absolute relief to affected low-income groups. Hence the aggregate MPC is likely to be small.

\section{Conclusions and Extensions}

The existence of liquidity constraints as a preexisting distortion is important in the determination of consumption behavior in a life-cycle model. Forced lifetime saving due to liquidity constraints is substantial, and if the intertemporal elasticity of substitution in consumption is small, the incorporation of borrowing constraints enables the life-cycle model to generate more realistic predictions about the size of the aggregate capital stock. Further econometric work on estimating the magnitude of 
the intertemporal elasticity of substitution in consumption will facilitate future policy analysis of the implications of liquidity constraints.

The normative side of our analysis has shown that consideration of liquidity constraints also will have a significant impact on how one views various tax changes. Many of the principal findings about the saving and welfare effects of tax reforms drawn from fiscal-policy simulation models rely heavily on the assumption that capital markets are perfect and that individuals can borrow and lend freely to smooth consumption in response to policy changes. When liquidity constraints are allowed for, theoretical predictions about the efficiency effects of altering the relative reliance on various tax bases or the degree of progressivity of the income tax are no longer clear.

Our conclusions here are two. First, arguments that reduced capital income taxation financed by increased labor income taxation raises individual welfare depend on a substantial interest sensitivity of saving in the life-cycle framework and on the ability of consumers with low current earnings to borrow to finance higher labor income taxes. With borrowing restrictions, the gains from higher saving rates and output must be weighed against the efficiency losses from the reduced consumption of constrained individuals. For some plausible parameter values, elimination of capital income taxation compensated by higher labor income taxation can reduce the welfare of a representative individual.

In a similar vein, recent analyses of progressive taxation focus on the disincentive effects on work effort and saving of high marginal tax rates. A move toward proportional taxation would indeed reduce these effects, but, in the presence of the borrowing constraints discussed here, would also reduce the consumption of constrained low-income individuals. We find that the use of an exemption and a higher marginal tax rate can in some cases improve efficiency relative to a proportional tax. That is, there may be significant efficiency gains from using exemptions. If we combine these findings with those from the capital taxation experiments, it may be that replacing capital taxes with a progressive tax on labor earnings could be efficiency-improving.

Further extensions that take into account similar restrictions will likely reinforce these conclusions. For example, an inability to insure against wage uncertainty implies that liquidity constraints may occur not only in the early and middle stages of life but also later if adverse 
wage shocks occur in those periods. The addition of uncertainty to the model would introduce portfolio decisions for the individual that would also be distorted by the liquidity considerations. Such distortions would likely be aggravated by tax policies that increase the severity of the liquidity constraints. While our analysis focuses on a tractable type of capital market imperfection, it is likely that the addition of more realistic elements will reinforce our results.

Finally, liquidity constraints are important for analyzing the effects of deficit-financed tax cuts on consumption. Liquidity-constraint considerations are likely to dominate finite-horizon effects in determining the aggregate marginal propensity to consume out of temporary tax cuts. In addition, the presence of a significant number of constrained consumers earning a nontrivial proportion of aggregate disposable income does not necessarily imply that temporary tax changes will be effective in modifying the level of consumer spending. In general, the distribution of tax changes matters. The benefits of past tax cuts have gone largely to highincome groups, so that measured effects on consumption could be small even with a substantial number of potentially affected consumers. Hence, it is difficult to make inferences about the aggregate importance of liquidity constraints from econometric studies of temporary tax changes.

Our findings suggest the importance of considering capital market imperfections as preexisting distortions in normative and positive analyses in macroeconomics and public finance. The results do not depend on any extreme form of optimizing behavior on the part of individuals or households. Similar results might also be obtained in approaches in which individuals force themselves to precommit to saving strategies to avoid deprivation because of a lack of self-control. Indeed, our formal conclusions are not inconsistent with the "quest for self-control" arguments of Thomas Schelling or of Richard Thaler and Hersh Shefrin as long as there is at least some period in which the "optimizing self", commits to plans to bind the "wastrel self." 78

78. T. C. Schelling, "Egonomics, or the Art of Self Management," American Economic Review, vol. 68 (May 1978, Papers and Proceedings, 1977), pp. 290-94; Thaler and Shefrin, "An Economic Theory of Self-Control." We do not seek to describe the evolution of particular institutions such as Christmas clubs or certain forms of private pensions. In fact, to the extent that such institutions are set up by an individual to impose discipline on himself and to provide for future needs, our model is implied by such considerations. 
Much more theoretical and empirical research is needed on taxpayers' decisions about consumption, saving, and labor supply and on the responsiveness of those decisions to public policies. Theoretical research should probe more closely the origins of liquidity constraints (and capital market imperfections more generally) in consumer finance and their implications for intragenerational and intergenerational issues in optimal taxation. Realistic consideration of imperfections in the markets in which taxpayers carry out their plans and the implications of these imperfections for "second-best" policy design is an important research strategy.

APPENDIX A

\section{Consideration of Elastic Labor Supply}

FOR THE CASE of variable labor supply, we rewrite the individual's lifetime utility function in equation 1 as being additively separable in consumption, $c$, and leisure, $l$ :

$$
\int_{0}^{T}[U(c)-V(1-l)] e^{-\rho t} d t
$$

where the labor endowment is normalized to unity (that is, labor supply, $L-$ - hours"-is equal to $1-l$ ). Again assuming an isoelastic utility function, we let

$$
\begin{gathered}
U(c)=\frac{1}{1-\beta^{-1}} c^{1-\beta^{-1}}, \text { and } \\
V(1-l)=\frac{\gamma}{1+\eta}(1-l)^{1+\eta},
\end{gathered}
$$

where $\gamma$ measures the intensity of leisure (that is, regulates the marginal rate of substitution between consumption and leisure) and $\eta$ is the compensated elasticity of labor supply.

Individual net earnings ( $E$ in the text) can now be decomposed as the product of the after-tax wage rate (per efficiency unit), individual 
productivity per hour, and hours worked. Denoting the gross wage, labor tax rate, and productivity by $w, \tau_{L}$, and $e$, respectively, we have

$$
E=\left(1-\tau_{L}\right) w e(1-l)=\tilde{w} L .
$$

Arbitrage conditions yield

$$
\begin{gathered}
U^{\prime}(C)=\lambda, \text { and } \\
V^{\prime}(L)=\tilde{w} \lambda .
\end{gathered}
$$

Hence labor supply is equal to

$$
L=\min \left[1,\left(\frac{\tilde{w} \lambda}{\gamma}\right)^{1 / \eta}\right]
$$

so that if $L<1$,

$$
\begin{gathered}
\tilde{w} U^{\prime}(c)=V^{\prime}(L), \text { or } \\
L=\left(\frac{\tilde{w} c^{-\beta^{-1}}}{\gamma}\right)^{1 / \eta} .
\end{gathered}
$$

In our parameterizations, we vary the intertemporal elasticity of substitution and the labor supply elasticity across a range suggested by various empirical studies. In varying these parameters, we also vary $\gamma$ so as to keep the consumption of leisure in the first period of life, if constrained, equal to 0.6 . This is done to model the observation that $40-$ 50 percent of available hours are spent on work. When we vary the interest rate we also adjust the wage profile to keep the wage-rental ratio constant. This adjustment ensures that we are examining the same production function as we vary our parameters.

Our specification of utility makes the special assumption of additive separability between consumption and leisure. This specification was assumed by MaCurdy. ${ }^{79}$ Also, MaCurdy estimates a more general utility function, but could not reject separability. ${ }^{80}$

For the human capital vector, $e$, we took Davies's fourth-degree polynomial estimate of earnings. An alternative would be the estimate by Welch for full-time workers with a high-school education. ${ }^{81}$ Auerbach,

79. Thomas E. MaCurdy, "An Empirical Model of Labor Supply in a Life-Cycle Setting," Journal of Political Economy, vol. 89 (December 1981), pp. 1059-85.

80. MaCurdy, "A Simple Scheme."

81. Welch, "Effects of Cohort Size." 
Kotlikoff, and Skinner used this in their study, though they omitted a term. ${ }^{82}$ Welch's estimated equation for human capital of a worker with $t$ years' experience is

$$
\ln e(t)=-.86 \max \{0,1-t / 7\}+.033 t-.00067 t^{2}+\beta_{0},
$$

where $\beta_{0}$ is the intercept term. Auerbach, Kotlikoff, and Skinner did not use the initial "spline" term, to use Welch's terminology. In their study, this choice probably was of no importance, but here it represents the difference between being liquidity constrained or not, the prime interest of our study. We do not report the results corresponding to the Welch specification of human capital endowment, since they were indistinguishable from the ones reported.

In the family case we use the Dolde family weights and household earnings profile. ${ }^{83}$ When the Dolde numbers are contrasted with the estimated family-size effects of MaCurdy and Gilbert Ghez and Gary Becker, they put relatively large weights on the consumption of a marginal family member. ${ }^{84} \mathrm{We}$ argue that the Dolde weights are an upper bound on the importance of family-size effects and therefore an appropriate limit case for us to examine and contrast with the single case that ignores family-size effects.

\section{Analytical Model of Borrowing Constraints and Consumption}

Agents ARE ASSUMED to maximize utility given by

$$
U=E_{T}\left\{\int_{0}^{T} e^{-\rho t} \ln c d t\right\},
$$

where the variables are as defined in the text.

82. Auerbach, Kotlikoff, and Skinner, "The Efficiency Gains."

83. Dolde, "Capital Markets."

84. MaCurdy, "A Simple Scheme"; Gilbert R. Ghez and Gary S. Becker, The Allocation of Time and Goods over the Life Cycle (National Bureau of Economic Research, 1975). 
The evolution of human capital of low- and high-productivity individuals ( $H_{1}$ and $H_{2}$, respectively) can be determined straightforwardly. Since a proportion $p d t$ of current high-productivity workers die during $(t, t+d t)$, and the market discounts future wealth at the interest rate, $r$, $\mathrm{H}_{2}$ obeys

$$
H_{2}(t)=w_{2} \Theta_{2} d t+(1-r d t)(1-p d t) H_{2}(t+d t) .
$$

This equation states that the current human capital of high-productivity workers equals the current wage flow plus the present value of the expected human capital of the current workers, who are a proportion $1-p d t$ of high-productivity workers $d t$ units of time in the future. (This appeals to the assumption that our population is in a steady state in which the number of transitions from low to high productivity equals the deaths of high-productivity workers.) This can be expressed as the differential equation

$$
\dot{H}_{2}=-w_{2} \Theta_{2}+(p+r) H_{2} .
$$

To determine $H_{1}$, we must take into account both deaths and transitions to high productivity. With probability $q d t$ a low-productivity worker becomes high-productivity, and with probability $p d t$ dies. Hence the current low-productivity workers are $1-(p+q) d t$ of tomorrow's low-productivity workers. The $q d t$ proportion that become high-productivity workers comprise a $p d t$ proportion of all such workers tomorrow, and hence tomorrow will have $p d t$ of $H_{2}$. Therefore,

$$
\begin{aligned}
H_{1}(t)= & w_{1} \Theta_{1} d t+(1-p d t)(1-r d t)\left[(1-q d t) H_{1}(t+d t)\right. \\
& \left.+p d t H_{2}(t+d t)\right] .
\end{aligned}
$$

In differential equation form, this becomes

$$
\dot{H}_{1}=-w_{1} \Theta_{1}+(p+q+r) H_{1}-p H_{2} .
$$

Financial assets per capita, $A$, follow

$$
\dot{A}=r A+w_{1} \Theta_{1}+w_{2} \Theta_{2}-\Theta_{1} c_{1}-\Theta_{2} c_{2},
$$

where $c_{1}\left(c_{2}\right)$ is the average consumption of low- (high-) productivity workers.

When borrowing against future earnings is not allowed, consumption of low-productivity workers may be equal only to the wage. In that case, 
we need only examine $H_{2}$ and $A$ in the aggregate analysis, since consumption equals the wage for all low-productivity workers. Hence,

$$
\begin{gathered}
\dot{H}_{2}=-w_{2} \Theta_{2}+(p+r) H_{2} \text {, and } \\
\dot{A}=w_{2} \Theta_{2}+r A-(\rho+p)\left(H_{2}+A\right) .
\end{gathered}
$$

If agents cannot borrow against future earnings, they may save in the initial low-productivity state. The following analysis determines the nature of savings and consumption paths for that case.

Since consumption when the high-productivity state is reached will be $(\rho+p)\left[A+w_{2}(p+r)^{-1}\right]$ if assets are $A$, the marginal value of assets at the moment of transition will be $(\rho+p)^{-1}\left[A+w_{2}(p+r)^{-1}\right]^{-1}$, which is $V^{\prime}(A)$ if $V(A)$ is defined to be the value of assets in the high-productivity state. An individual in the low-productivity state will therefore face the following problem:

$$
\begin{gathered}
\max \int_{0}^{\infty} e^{-(\rho+p+q) t}[\ln c+q V(A)] d t, \text { subject to } \\
\dot{A}=(r+p) A+w_{1}-c .
\end{gathered}
$$

This problem differs because the budget constraint does not include any insurance payment a worker receives when he fails to move to high productivity. That insurance was implicitly assumed above when we focused on perfect capital markets. Arbitrage implies that

$$
\dot{c}=(\rho+q-r) c+\frac{q c^{2}}{(\rho+p)(A+h)} .
$$

Phase-diagram analysis of equation B10 and the budget constraint in equation B9 shows that, if $q$ is high and assets are initially zero, lowproductivity individuals consume their wage. 


\section{Comments and Discussion}

Robert E. Hall: I admire Glenn Hubbard and Kenneth Judd's daring in presenting a long and detailed defense of the proposition that the United States saves too much. Thanks to our society's unwillingness to let young people borrow against future earnings, our capital stock may be close to double its optimal size, according to their findings. Policies that would help families save less over their lifetimes-for example, a larger exemption in the income tax-would raise national welfare. The paper is a refreshing change from the prevailing view that saving and capital formation are inadequate in the United States of the eighties. Of course, Hubbard and Judd agree that other factors probably work in the opposite direction, to discourage saving.

The basic idea of the paper is one supported by the findings of a number of authors recently: the young would like to have negative net worth, but nobody will lend to them because of bankruptcy law and other reasons. Consequently, the young keep their net worth at exactly zero; that is, they consume all of their income. Empirical studies confirm that relatively few young families have positive net worth, especially net worth outside of housing equity.

Hubbard and Judd give a good deal of attention to intergenerational issues in the family. They point out that the expectation of inheritance in late middle age only worsens the problem of suboptimal consumption by the young. Loans and gifts inter vivos could go the other way, but the authors consider this unlikely to have an important effect in lessening the burden of liquidity constraints.

My point of maximum discomfort with this line of thought relates to the role of the family. It is well within the capabilities of many familiesperhaps a majority - to overcome the problem of suboptimal consump- 
tion. Yet it is my impression that relatively few do. Most family loans and gifts are for human capital, business, or house purchases, not acceleration of consumption (though often acceleration is a secondary effect).

If families could solve the problem of oversaving but choose not to do so, it raises the question of whether the problem exists. One possibility is that the desired level of consumption for the young is not very far above actual consumption, so that the burden of the net worth constraint is low. Hubbard and Judd's model considers life-cycle patterns in consumption related to family size, but not related strictly to age. If people in their twenties normally choose simpler life-styles than those in their thirties and older do, then Hubbard and Judd have overstated the amount of oversaving and its welfare costs.

A second possibility, and the one I take more seriously, is that families remain paternalistic long after their offspring reach official adulthood. Parents don't let their young adult children consume out of their future income expectations until they have proven themselves. Or the parents enforce their own views about limiting consumption by refusing to lend or to make gifts.

Hubbard and Judd make some cautious comments about modifications in social security to take account of oversaving. They suggest a more progressive payroll tax. In terms of their model, a better idea is to excuse the young from the tax and to pay them benefits instead. Under the optimal plan in the light of their model, social security would pay beneficiaries until they reach age thirty, collect taxes until they retire, and then pay benefits again. An individual's implicit debt to social security could not be discharged in bankruptcy, so negative net worth would be feasible. Such a system would avoid a good deal of the oversaving that takes place in the economy today, according to the model.

Some retirement systems do not require contributions from workers under age thirty, so there is some recognition of the point Hubbard and Judd raise. However, I think it is safe to predict that a proposal to pay social security benefits to young adults would not attract a single vote in Congress. Underconsumption and oversaving by the young is not perceived as a national problem at all.

The paper demonstrates very effectively that consumers' flexibility about the timing of consumption is of central importance in dealing with 
life-cycle consumption issues. If the public substitutes easily between present and future consumption-that is, if the elasticity of intertemporal substitution is high - the welfare costs of underconsumption among the young are small. My own work on this point suggests that intertemporal substitution is low. I think, for example, that the most relevant line in table 3 is the last, where constraints have the largest effects. That is, I am skeptical that underconsumption is such a problem, but to the extent that it occurs, it is costly to welfare because people strongly prefer level consumption paths.

Similarly, I believe that a shift from interest taxation to wage taxation, in which the wage tax bears fully on the young (illustrated in table 4), may depress welfare, despite the case for a consumption tax in a perfect economy. Again, this endorsement is qualified by my skepticism about underconsumption.

With respect to the conclusion in favor of an exemption against labor income, shown in table 6, I choose the lowest line, which has the largest welfare gain. My endorsement on this point is not qualified, because I believe in the exemption on distributional grounds anyway. If the exemption has an efficiency justification as well, along the lines suggested by Hubbard and Judd, so much the better.

Again, I congratulate the authors for pushing their analysis of oversaving so far. I still give a lot of weight to the decisions made by millions of families when they choose not to solve the problem themselves. Those families obviously don't agree with the premises of this analysis. Yet I have to concede that Hubbard and Judd have persuaded me that, to the extent there are unsolved problems of liquidity constraints, many important conclusions about fiscal policy emerge.

Lawrence Summers: Glenn Hubbard and Kenneth Judd's ambitious paper attempts to make the case that liquidity constraints are of pervasive importance for the positive and normative analysis of fiscal policies. The authors suggest that a number of traditional conclusions about alternative fiscal policies need to be reassessed in light of the recognition that many consumers are liquidity constrained. In particular, they conclude that under some circumstances capital taxation may be welfare-improving and that progressive taxes may enhance economic efficiency as well as equity. I am largely convinced that Hubbard and Judd's conclusions follow from their assumptions-indeed, at some points the leap from 
assumptions to conclusions is a very short one. On the other hand, it is far from clear to me that the assumptions made by Hubbard and Judd are sufficiently realistic to permit any but the most remarkable intellectual athlete to jump from their results to judgments about the world.

Let me begin by motivating the Hubbard-Judd argument in a somewhat different way than they do. In traditional microeconomic theory the deadweight loss from taxation is of literally second-order importance. It depends on the square of the tax rate, so the first little bit of tax burden has no welfare implications. This argument presumes, however, that but for the introduction of taxes, the economy is at an optimal competitive equilibrium. Once preexisting distortions are introduced, taxes have first-order effects on economic welfare that, it is reasonable to suppose, are more important than second-order effects. Hence the analysis of the effect of taxes in environments where there are preexisting distortions would seem to be a high priority for public finance research. Yet surprisingly little of it has been done.

Hubbard and Judd are to be applauded for attempting such an analysis. The preexisting distortion on which they focus is the presence of liquidity constraints. The argument is that individuals systematically consume less early in life and more late in life than they wish because liquidity constraints preclude their borrowing to smooth consumption in the way that they would like. The absence of a consumer loan market is the failure of the standard competitive assumptions that drives their analysis. Because of the constraints, individuals are unable to satisfy the standard requirement that the marginal utility of a dollar devoted to consumption early in life and that of a dollar devoted to consumption late in life be equalized. Because the marginal utility of consumption is higher early in life, any policy that raises the after-tax income of the young relative to the after-tax income of the old raises welfare. The average recipient of capital income is older than the average recipient of labor income. Hence the liquidity-constraint consideration works to make capital taxes look good. The old are richer than the young, so progressive taxation also redistributes in a favorable way.

To state the argument is to highlight its indirection. We usually think of intragenerational rather than intergenerational equity as being of dominant importance in thinking about progressive taxation. The shifts in the tax burden between capital and labor have many consequences that are more important than the resulting redistribution between capital 
and labor. Hubbard and Judd shrink from some of the direct implications of a finding that liquidity constraints are an important distortion in the economy. Neither progressive taxation nor capital taxation seems a natural instrument to dedicate to this problem. ${ }^{1}$ A more direct alternative would be reversing the direction of transfers under the social security system or, more modestly, allowing individuals to use their social security benefits as collateral and borrow. Extending to Sears-Roebuck the sort of long arm of the law that is exercised on behalf of welfare mothers would also relax liquidity constraints. Granting for the moment the social importance of liquidity constraints, I think they should be attacked through means much more direct than increasing the progressivity of the tax system.

But a much more profound problem with the Hubbard-Judd analysis is that it pushes the standard intertemporal utility maximization model of consumption well past the breaking point. The authors are quick to attribute any deviation from the predictions of the model to liquidity constraints that they then regard as a distortion. It is this conclusion that drives their results. An alternative interpretation of the close relationship between consumption and income would deny the premise that individual behavior is well captured by the intertemporal maximization hypothesis. In this case, Hubbard and Judd's welfare calculations would not be appropriate.

Let me illustrate this point. There is a tradition at the Brookings Panel of discussants presenting handouts of empirical work hot off the computer. I want to do some real-time empirical work in keeping with the long lead times you usually receive on my papers. How many people in this room have already made their full IRA contribution for tax year 1986, the one due in April 1987? Raise your hand if you have. [Editors' note: fewer than half of the participants raised their hands.] As I would have gliessed, many have not. And I suspect that it would be difficult in most cases to rationalize your hesitation by pointing to liquidity constraints, even though for almost all of us it would be rational to put the money away now. Some sort of preference for liquidity or some difficulty in making decisions must explain our behavior. Neither is well captured

1. I discuss instrument choice in the context of savings policy in Lawrence H. Summers, "Issues in National Savings Policy," in F. Gerard Adams and Susan M. Wachter, eds., Savings and Capital Formation: The Policy Options (D.C. Heath and Co., 1986), pp. 6588 . 
by the intertemporal maximization model used in this paper. Either would lead to rejections of the life-cycle model like those described in the paper. This suggests that it may be unrealistic to assume that liquidity constraints are the explanation for evidence suggesting that consumption and income are closely associated.

The point can be made more strongly. America's largest social program, social security, is premised to no small degree on the view that individuals are not rational in preparing for old age and need to be coerced to do so. The existence of TIAA-CREF as a custodian of the retirement funds of many of us in this room is due to a conviction that college professors cannot be trusted to save enough for their own or their spouses' old age. If important, these behavior patterns are likely to dwarf liquidity constraints in explaining consumption and saving. Indeed, liquidity constraints arise in no small part from rules that are explicitly designed to prevent the profligate from getting in too far over their heads. Hubbard and Judd assume these considerations away entirely on their way to favoring tax reforms that would redistribute wealth toward the young. (I wonder what their view will be twenty-five years from now.) Most of us shrink from the direct implication of the Hubbard-Judd view of liquidity constraints, and I think this is the reason why.

Although I have focused primarily on the normative component of the Hubbard-Judd paper, the paper also addresses positive issues regarding the importance of deficits. I want to underscore one point it makes that parallels a conclusion I came to in some work with James Poterba: the issue of the finiteness of life is not important in evaluating the economic effects of budget deficits. ${ }^{2}$ Human lives, while short in terms of geological time, are long in terms of economic time. While government debt policies shift liabilities to future generations and therefore affect consumers' wealth and consumption, the effect is not empirically consequential except for extremely long-lived deficits. The vast majority of the debt incurred during World War II was repaid within the lifetime of persons alive at the time the war was fought. The same is likely to be true for those of us alive during the current debt buildup.

2. James Poterba and Lawrence Summers, "The Macroeconomic Irrelevance of Finite Lives"' (MIT, 1986). 
Hubbard and Judd correctly focus the debate over Ricardian equivalence on the question of the consumption-income relationship rather than on the nature of bequest motives.

I conclude with a methodological note. I wonder how much we learn about tax policies from simulation studies of stylized economics of identical individuals who differ only by the date of their death and save only by directly holding riskless capital. Using computers to expand the back of one's envelope is one thing, but heeding the results is quite another. Anyone who has paid any attention to tax debates cannot help but be struck by the irrelevance of measures of excess burden to the participants. Perhaps this reflects failures of education by economists. More likely it reflects the weight given to issues other than economic efficiency in the standard sense of the term. In neither event is it especially helpful to measure efficiency in ever more complicated simulation models. Rather, I would hope that economists would turn their attention to examining the effects of tax policies on economic behavior without the prism of optimization theory used in so many studies. The theory is a useful touchstone, but like a prism it may distort more than it reflects. Someday we will have a much greater understanding of the effects of tax policies on saving behavior, but I doubt very much that it will come when we know the true gamma, delta, or any other Greek letter of the representative consumer.

\section{General Discussion}

Acknowledging that one could quarrel with details of the authors' specification, James Tobin applauded the paper for showing the potential importance of liquidity constraints in thinking about tax policy. Gregory Mankiw cautioned that available evidence may be insufficient to establish the empirical significance of liquidity constraints. He noted that the evidence cited by Hubbard and Judd consists primarily of findings that consumption exhibits excess sensitivity to changes in income, and he argued that existing statistical tests are potentially biased in favor of that finding. Standard test procedures assume that income is stationary around a deterministic trend; they are invalid if income follows a nonstationary process, a condition that appears empirically relevant. 
Hubbard responded that the low levels of assets held by many households and of unsecured consumer debt relative to collateralized debt also favored the liquidity-constraint interpretation of the data.

Several members of the panel took exception to the inference drawn by the formal discussants that liquidity constraints affecting young households were probably not important, because if they were, the political process and other institutions would have created mechanisms to transfer resources to those households. Charles Schultze noted that, as a teacher at a public university, he was sensitive to the fact that society and politicians had indeed found it worthwhile to transfer resources to individuals in their late teens and early twenties. William Brainard observed that some academic institutions have begun to recognize the mismatch between earnings and consumption needs over the life cycle. At Yale and some other universities, the retirement plan contributions required from junior faculty members are lower than those required from senior faculty members. The political pressure for student loan programs can be similarly interpreted. William Branson noted that the negative income tax, an idea that at one point enjoyed a certain political appeal, would have transferred income from older workers to younger workers.

Several discussants provided arguments against shifting income from older to younger individuals. Martin Baily commented that many parents choose not to give their adolescent and young adult children money to spend on increased consumption, fearing that such transfers might interfere with the development of good work habits. A similar argument can be made against the transfer of public funds to the young. Robert Gordon cautioned against altering the tax structure to flatten the profile of take-home pay over the life cycle, noting that incentive considerations might make it optimal for an employer to defer earnings from early until late in an employee's tenure with the firm. Changes in the tax structure that increased the relative take-home pay of junior workers might interfere with this sort of incentive scheme. Katharine Abraham cited evidence that earnings grow more rapidly than productivity not just with time on a specific job, but also with age. This evidence cannot be explained by implicit contracts such as those to which Gordon referred, but may reflect a more general societal consensus concerning the appropriate path of earnings over the life cycle. If individuals derive utility both from consumption and from growth in consumption, Abra- 
ham continued, the conclusions of a welfare analysis of the sort in Hubbard and Judd's paper could be altered.

Abrahamalso commented that the introduction of large-scale transfers from older workers to younger workers would reduce the lifetime utility of today's older workers, who have already passed the age at which they might benefit from the program. Even if such transfers could produce steady-state welfare gains, the distribution of losses and gains from the introduction of the program could block its passage. In contrast, most people of voting age in 1935 stood to benefit from the introduction of the social security system.

Alan Blinder noted that Hubbard and Judd have modeled only those liquidity constraints arising from the divergence of the typical individual's desired life-cycle consumption profile from the typical life-cycle income profile. Unexpected shocks to earnings, such as might be experienced during an extended spell of unemployment, are another potentially important source of liquidity constraints. Hubbard responded that the simulations reported in the paper were intended to yield lowerbound estimates of the welfare benefits that might be obtained by tax changes that relieved those constraints. He also commented that augmenting the basic model to incorporate uncertainty and the possibility that workers might hold precautionary balances would probably not affect the basic policy conclusions but might make the simulated capitalto-output ratios more realistic. 